\title{
EDEMA OF THE PIA-ARACHNOID
}

\author{
ITS NATURE, SIGNIFICANCE, RELATIONSHIP TO AND ASSOCIATION WITH \\ DISEASE PROCESSES * \\ CHARLES K. STILLMAN, M.D. \\ NEW YORK
}

\section{INTRODUCTION}

The following article is a study of the nature and significance of fluid accumulations within the subarachnoid space, based principally on post-mortem observations and mechanical considerations.

For the sake of brevity it may be stated at the outset that the terminology employed to designate the various conditions of the brain and its membranes associated with excessive fluid accumulations has been confused by the use of many names, employed without due consideration of the etiological or mechanical factors involved. It is therefore necessary to describe the various anatomical findings to which these different terms have been applied.

1. Pial Edema; Edema of the Pia Mater; Edema of the Pia Arachnoid; Cerebral Edema; Wet-Brain.-These terms have been employed indefinitely to designate conditions accompanied by excess of fluid in the pia-arachnoid. The brain on cut section may or may not appear to be moist; the ventricles may or may not be "dilated." The volume of the brain is not increased, on the contrary it often has given the impression of having been compressed. It is this picture which is generally associated with and attributed to chronic alcoholism, and which in this country has often been referred to as wet-brain.

2. Cerebral Edema; Edema of the Brain.- Swelling of the brain with increase in its volume. The pia-arachnoid may or may not have contained an excess of fluid; usually the convolutions are described as flattened, owing, as supposed, to pressure of the voluminous brain against the skull. These brains are then described as being moist, the condition being usually attributed to transudation into the brain substance of serum from the blood-vessels.

3. Serous Meningitis.-Described usually as a serous or exudative inflammation of the soft meninges, with exudate into the subarachnoid space and its prolongations, with or without gross thickenings of the

*Accepted for publication March 31 .

*From the Pathological Laboratories of Bellevue Hospital, Dr. Charles Norris, Director. 
meninges. The rentricles may or may not be dilated and the brain is or is not secondarily involved, the seat of an edematous or inflammatory process. Certain writers in this country, notably Dana, have regarded "alcoholic wet-brain" and serous meningitis as synonymous.

4. Hydrops ex Vacuo.-This term has been used to describe the accumulation of fluid following the shrinkage of the brain from old age or from various pathological causes, to be mentioned later.

5. Chronic External Hydrocephalus.-This term has been used to describe those appearances already referred to above; by some authors, also, to describe accumulations of fluid in the subdural space and even those found between the calvarium and the dura mater. ${ }^{1}$

The above summary, derived from a critical survey of the literature, shows that these various terms, althongh in themselves perfectly clear and descriptive, have been used indiscriminately to designate different anatomical conditions without any consideration of the underlying pathological processes in which they had their origin.

Although the older writers did not formulate any noteworthy theories as to the causation of excessive accumulations of fluid in the brain, ${ }^{2}$ they nevertheless displayed considerable interest in its supposed mechanical effects. Thus we find in Watson's Lectures ${ }^{3}$ (1845), the following rather quaint description of fluid collections in the pia-arachnoid in connection with uremic coma.

Now when death had thus taken place in the way of coma and the case had been complicated with anasarca, and serous liquid is found accumulated in unnatural measure in the cerebral ventricles, and in the tissue of the pia mater, it seems reasonable to ascribe the coma to the presence and the pressure of that liquid. The dropsy has extended to the brain. And this view of the matter is strengthened by the connection which may sometimes be noticed between the accession of the coma and the visible increase of the dropsy in other parts of the body. My own experience accords entirely with that of Dr. Christison as expressed in the following statement: "If the dropsical fluid be allowed greatly to accumulate, drowsiness, the first symptom of the affection of the head, very soon makes its appearance in the generality of cases and it will speedily pass to fatal coma if not controlled, but the removal of the dropsy will usually remove the drowsiness." To many cases, however, this explanation will not apply, there being no morbid collection of water within the skull, nor any other appreciable change there; nor perhaps, any dropsy elsewhere.

The fluid collections described by Watson were doubtless that very common form of pial effusion with which this paper particularly has to do.

In 1861, Traube 4 opened up a new vista in the field of intracranial mechanics by stating that the brain is often swollen and edematous in 207.

1. Riva, E.: Idrocephalo interno ed esterno, Riv. sper di freniat, 1908, xxxiv,

2. Traube quotes Osborne as attributing the condition to an arachnitis.

3. Watson, Thomas: Principles and Practice of Physics, London, 1845.

4. Traube, L.: Eine Hypothese über den Zusammenhang, in welchem die sogenannten urämischen Anfïlle zur Erkrankung der Nieren stehen, Allg. med. Centr.Ztg., 1861, xxx, 818 . 
certain cases of uremia. Since Traube ${ }^{5}$ may thus be regarded as the founder of a new school, a somewhat detailed consideration of his paper is imperative. In discussing uremia he says: "In all cases observed by me in which a careful examination of the cranial contents has been made after death, there was observed with a well-marked anemia [Blut-Armuth] of the brain, a more or less considerable edematous swelling of the same (as shown by flattening of the brain convolutions and dryness of the arachnoid, with moist glistening of the cut section)." Further on he writes: "In some of these cases the fresh petechiæ [Blut-Ergüsse] were distributed in the form of fine sand up to hemp-seed foci through the large and small brain and pons due," as he states, "to increased arterial pressure." He lays especial stress upon two factors in the causation of brain edema in uremia ; first, the hydremic condition of the blood, due to loss of albumin through the urine and through gastro-intestinal catarrh, and second, to the increased tension in the aortic system from hypertrophy of the left ventricle. ${ }^{5}$ He goes on to say:

If through any accidental cause there occurs a sudden increase of bloodpressure, or if there is a sudden diminution in the thickness of the blood-serum, there transudes a serous fluid through the walls of the small arteries into the brain substance, and thus brain edema ensues. The fluid elements of the blood transude under the mean pressure in the aortic system. Since this pressure is greater than that in the capillaries and veins, so these vessels must finally be compressed. The necessary consequence of a brain edema arising from such a cause is an anemia of the brain substance. The transudation, as will be readily understood, resists up to the moment when the tension of the edematous brain parts equals the mean tension of the aortic system.

Traube's explanation of the causes bringing about transudation is not generally accepted. He cites a case of cerebral edema in an epileptic who at autopsy was found to have a cysto-sarcoma of the brain. There is reason to believe that from this case he derived the idea on which he founded his theory as to the causation of the attacks of coma and convulsions occurring in cases of uremia and of chronic lead-poisoning.

Several years after Traube's paper appeared, Billroth ${ }^{\mathbf{3}}$ (1869) observed anatomical changes in the brains of postoperative subjects somewhat similar to those described by Traube.

Niemever ${ }^{9}$ (18\% ) and Huguenin ${ }^{10}(18 \% 8)$ reconsidered the problem chiefly in connection with the phenomena of uremia. $1,551$.

5. Traube, L.: Gesammelte Beiträge zur Pathologie und Physiologie, ii, Part

6. Traube, L.: Gesammelte Beiträge zur Pathologie und Physiologie, ii, Part 1, p. 553.

7. Traube, L.: Gesammelte Beiträge zur Pathologie und Physiologie, ii, Part 1, p. 554.

8. Billroth: Ueber akute Mening. serosa und akute Gehirnödem nach chirurgischen Operationen, Wien. med. Wchnschr., 1869, xix, 2.

9. Niemeyer: Lehrbuch der speziellen Pathologie und Therapie, Ed. 9, 1877, ii.

10. Hugenin, G.: Hrdrocephalus und Oedem des Hirns, Handbuch der speziellen Pathologie und Therapie von v. Ziemssen, Suppl. Vol., 1878, p. 25. 
Bergmann ${ }^{11}$ (1880) described an edematous condition in connection with injuries of the brain, while Dean ${ }^{12}$ produced local edema experimentally by placing a glass disc between the brain and the dura.

Phelps $^{13}$ (1897) believes that edema of the brain may follow on contusion and W. N. Bullard ${ }^{14}$ (1895) states that edema of the brain results from concussion. The latter writes:

Brain swelling undoubtedly occurs in certain cases of apoplexy, and in a chronic form in many intracranial diseases. This, or something analogous to it, the so-called acute edema of the brain, is the immediate cause of death in cases of acute alcoholism, of sunstroke and perhaps (in its chronic form) in uremia.

Walton and Brooks ${ }^{16}$ (1897) have also dwelt on the subject of edema of the brain and its membranes from a surgical standpoint. Walton in his subsequent paper $^{17}$ has considerably modified his previous conceptions.

W. B. Cannon ${ }^{18}$ in an article published in 1901, presented certain striking and original conclusions on the causation of cerebral edema following trauma, which will be later referred to, while at about the same time Mott ${ }^{19}$ succeeded in producing experimental edema of the brain in dogs by ligation of arteries, and Osler20 (1901), following Traube, described cerebral edema particularly in connection with uremic coma.

The subject of cerebral edema has aroused great attention among physiologists only within a comparatively recent period. Wilson ${ }^{21}$ (1904) studied the condition in connection with uremic and eclamptic seizures.

11. Bergmann: Die Lehre von den Kopfverletzungen, Deutsch. Chir., Stuttgart, $1880, \mathrm{xxx}, 420$. 1,26 .

12. Dean, H. P.: Cerebrospinal Pressure, Jour. Path. and Bacteriol., 1893,

13. Phelps, C.: Traumatic Injuries of the Brain and Its Membranes, New York, 1897, p. 53.

14. Bullard, W. N.: A Consideration of Some of the Indications for Operation in Head Injuries, Med. and Surg. Rep., City Hosp., Boston, Series 6, 1895, p. 60.

15. Bullard, W. N.: Increase of Intradural Pressure in Head Injuries, Boston Med. and Surg. Jour., 1898, cxxxviii, 271.

16. Walton, G. L., and Brooks, W. A.: Observations on Brain Surgery Suggested by a Case of Multiple Cerebral Hemorrhage, Boston Med. and Surg. Jour., 1897, cxxxvi, 301.

17. Walton, G. L.: Subarachnoid Serous Exudation Productive of Pressure Symptoms after Head Injuries, Am. Jour. Med. Sc., 1898, cxvi, 267.

18. Cannon, W. B.: Cerebral Pressure Following Trauma, Am. Jour. Physiol., 1901, vi, 91 .

19. Mott, F. W.: Preliminary Communication on the Changes in the Brain, Spinal Cord, Muscles and Other Organs Found in Persons Dying after Prolonged Epileptiform Convulsions, Arch. Neurol., London, i, 493.

20. Osler, Wm.: Practice of Medicine, 1901, p. 997.

21. Willson, R. N.: The Pathogenesis of Uremia and Eclampsia, Jour. Am. Med. Assn., 1904, xliii, 1019. 
B. Bramwell ${ }^{22}$ (1906) mentioned cerebral edema as a possible cause of uremic attacks. The following year A. E. Russell ${ }^{23}$ (190\%) introduced his thesis in the following terms: "The purpose of this paper is to put forward the proposition that there is evidence to show that the cerebral manifestations of uremia are dependent on cerebral anemia produced by an increase in intracranial tension resulting from cerebral edema." Following Russell, Cushing and Bordly ${ }^{24}$ (1908) published a paper based chiefly upon the observations and findings ante and post mortem in a case of uremia in which decompression was performed, as a result of which he concludes: "In regard to uremia, therefore, to be conservative we may at least say that the symptoms are elicited by edema resulting from some toxic agency, and are not, as is commonly supposed, due to the direct effect on the cerebral tissues of the toxic agent alone."25

Russell ${ }^{26}$ has very recently (1909) presented additional evidence supporting the hypothesis that the presence of edema of the brain is an important factor in the production of uremic phenomena. He says, speaking of Cushing's decompression case (mentioned above) and other recent data :

The foregoing facts indicate that in uremia a state of increased intracranial tension is present, and that relief of pressure by lumbar puncture or decompression causes a marked alleviation of the symptoms. Traube's view that cerebral edema (which would produce the rise in the intracranial tension) produces anemia of the brain is strongly supported by the above facts and especially by the striking ease of decompression.

Russell does not deny a concomitant toxic action on the brain but thinks it possible that status epilepticus may be due to an anemia of the brain following on a prolonged increase of intracranial pressure. There is, as has been shown, a very strong tendency among the members of the Traube school to assume that the rise in intracranial tension is due to cerebral edema. As a matter of fact cerebral edema is a very inconsistent phenomenon in uremia, as has been noted not only by Russell but by Bramwell, and by a large number of authors who are not identified with

22. Bramwell, B.: Clinical Lecture on Cremia and its Treatment, Clinical Studies, Edinburgh, 1906, Part 1, p. 1.

23. Russell, A. E.: Uremia, West. Lond. Med. Jour., 1907, xii, 9. This paper contains an excellent bibliography of the use of lumbar puncture in uremia.

24. Cushing, H., and Bordley, J., Jr.: Subtemporal Decompression in a Case of Chronic Nephritis with Uremia, etc., Am. Jour. Med. Sc., 1908, cxxxvi, 484.

25. Cushing has dealt with the subject to a less extent in previous papers, See Am. Jour. Med. Sc., 1903, cxxv, 1017.

26. Russell, A. E.: The Gouldstonian Lectures on Some Disorders of the Cerebral Circulation and Their Clinical Manifestations, Lancet, London, 1909, 1, 963, 1031, 1093 .

27. Huguenin, Ibid. 
the Traube school, namely, Huguenin, John Rose Bradford, ${ }^{28}$ Senator ${ }^{29}$ and Riesman. ${ }^{30}$

In this connection the observations of Kolisko ${ }^{31}$ on swollen and edematous brains, are most interesting. This observer has described a type of brain in which the brain is swollen and wet, the ventricles reduced in size and the fluid of the subarachnoid space diminished or absent, the convolutions flattened, associated with dural hernias, and marked impressiones digitates - the latter being due to a compression atrophy of the inner table of the skull described as following upon a premature ossification of the cranial sutures.

The clinical phenomena in these cases have not appeared to bear much resemblance to those recorded by the Traube school.

The term "serous meningitis," the etiological and anatomical status of which is intimately involved in any consideration of sub-arachnoid effusions, is of comparatively recent introduction, although its employment antedates the bacterial era of medicine.

Since the development of our subject depends chiefly on anatomical rather than general clinical considerations, we shall regard serous meningitis chiefly from the anatomical and mechanical point of view, and limit our review of it.

Among earlier writers it was usual to ascribe all cases of internal and external hydrocephalus to tuberculous meningitis, although certain observers, notable among whom were Dietl, ${ }^{32}$ Rokitansky, ${ }^{33}$ Wunderlich ${ }^{34}$ and Leubuscher ${ }^{35}$ did not agree with this opinion.

In 1869 Billroth $^{35}$ distinguished a form of acute hydrocephalus of supposed non-tuberculous origin to which he applied the name of meningitis serosa. But it was not until Eichorst ${ }^{\mathbf{3 6}}$ (1887) published his observations that much emphasis was laid on the idea that a simple serous inflammation was the pathological process in many of these cases.

28. Bradford, John Rose: Observations on the Pathology of the Kidneys. Gouldstonian Lectures, Lancet, London, 1898, i, 917.

29. Senator: Diseases of the Kidneys, Nothnagel's Encyclopedia, Am. Ed., p. 103 .

30. An analysis of the fourteen autopsies on cases of uremic aphasia, quoted by Dr. D. Riesman, Uremic Aphasia, Jour. Am. Med. Assn., 1902, xxxix, 883. shows six in which there was moisture of the brain or edema. One had marked distention of the right ventricle and the remaining seven brains were described as normal.

31. Kolisko, Alexander: Plötzlicher Tod aus natürlicher Ursache, Handbuch der ärztlichen sachverständigen Tätigkeit. Vienna and Leipsic, 1906, ii, 702 et seq.

32. Dietl: Anatomischer Klinik der Gehirnkrankheiten, 1846.

33. Rokitansky: Lehrbuch der pathologischen Anatomie, 1856, ii, Ed. 2.

34. Wunderlich: Die Pathologie und Therapie, 1854, iii, Ed. 2. 1854.

35. Leubuscher: Die Pathologie und Therapie der Gehirnkrankheiten, Berlin,

36. Eichorst: Handbuch der speziellen Pathologie und Therapie, 1887, iii. 
Eichorst believed that the process was due to a mild infection and remained serous throughout, while Gowers ${ }^{37}$ (1892) described the process as a meningitis simplex as distinguished from a meningitis purulenta. He was followed shortly by Quincke ${ }^{\mathbf{e s}}$ who elaborated a definite symptomatology for this disease.

The literature of serous meningitis has become so enormous that it is out of the question to attempt to review it, especially since Boenninghaus $^{39}$ has given a comprehensive summary of the subject up to $189 \%$ and Hafslauer ${ }^{40}$ has subsequently reviewed it up to 1906.

The subject did not receive much attention in the United States until Dana $^{41}$ (1897) published his article entitled "Acute Serous Meningitis (Alcoholic Meningitis, Wet-Brain)." Since then, articles, monographs or reports of cases bearing on the subject have appeared in this country by Lambert,, ${ }^{42}$ Smith, ${ }^{43}$ West, ${ }^{44}$ Gradle, ${ }^{45}$ Stillman,, ${ }^{46}$ Fischer, ${ }^{47}$ Diller, ${ }^{48}$ Collins, ${ }^{49}$ Tod, ${ }^{50}$ Spiller $^{51}$ and Stein ${ }^{52}$, and abroad, either coincidently with or since Hasslauer's summary by Verhoogen, ${ }^{53}$ Hasslauer, ${ }^{54}$ Blau, ${ }^{85}$

37. Gowers: Diseases of the Nervous System, 1892, ii.

38. Quincke: Ueber Meningitis serosa, Samml. klin. Vortr., new series, No. 67, 1893, p. 655. Also Ueber Meningitis serosa und verwandte Zustände, Deutsch. Ztschr. f. Nervenh., 1896, pp. 149-168.

39. Boenninghaus, G.: Die Meningitis serosa acuta, eine kritische Studie, Wiesbaden, 1897.

40. Hafslauer: Ueber Meningitis serosa, Sammelreferat internationales, Centralbl. f. Ohrenh., 1906, iv, Part 8, p. 341.

41. Dana, C. L.: Med. Rec., New York, 1897, lii, 801.

42. Lambert, A.: Alcoholism, Osler's Modern Medicine, 1, 157; Bellevue Hosp. Med. and Surg. Rep., 1904, 1, 113.

43. Smith, E. T.: Meningitis Serosa, Tr. Am. Otol. Soc., New Bedford, Mass., $1907, \mathrm{x}, 550$.

44. West, J. P.: Serous or Posterior Basic Meningitis; Its Early Recognition and Treatment, Ohio State Med. Jour., 1909, v, 323.

45. Gradle, H.: A Case of Serous Meningitis, Jour. Nerv. and Ment. Dis., 1906, xxxiii, 126.

46. Stillman, C. K.: Postdelirious Alcoholic Stupor, Alcoholic Cerebral Edema, (Wet-Brain), New York Med. Jour., 1908, lxxxvii, 154.

47. Fischer, J. S.: Serous Meningitis, Maryland Med. Jour., 1908, li, 158.

48. Diller: A Case of Serous (Alcoholic) Meningitis Simulating Brain Tumor, Jour. Nerv. and Ment. Dis., 1898, xxv, 441.

49. Collins, J.: Diseases of the Meninges, Twentieth Century Practice of Medicine, N. Y., 1897, x, 355.

50. Tod, H.: Lateral Sinus Thrombosis; Subsequent Meningitis (Meningitis Serosa) ; Recovery, Otol., sec. 30-32, Proc. Roy. Soc. of Med., 1907-1908, i, 30.

51. Spiller, William G.: Circumscribed Serous Spinal Meningitis, Am. Jour. Med. Sc., 1909, cxxxvii, 95.

52. Stein, R.: Serous Meningitis in Typhoid Fever and Its Treatment by Lum. bar Puneture, Am. Jour. Med. Sc., 1910, cxxxix, 542.

53. Verhoogen, R.: La méningite sereuse, Jour. d. méd., Brux., 1907, xii, 111.

54. Hafslauer: Die bakteriologischen Befunde bei der eiterigen und serösen Meningitis mit besonderer Berücksichtigung die bei der Lumbalpunktion, etc., Internat. CentralbI. f. Ohrenh., Leipsic, 1906-7, i, 65.

55. Blau, A.: A Case of Serous Meningo-Encephalitis with Autopsy Report, Ztsehr. f. Ohrenh., 1906, lii, 129. 
Avellis, ${ }^{56}$ Riebold, ${ }^{57}$ Thiemich, ${ }^{58}$ Paradis, ${ }^{59}$ Axhausen $^{60}$ and L. Williams ${ }^{61}$. A notable phase in the development of this subject of serous meningitis in the last few years has been the interest and attention which it has received from otologists.

The etiology is so much in dispute and the descriptions of this process by various writers are so divergent, not only from the clinical but also from the anatomical standpoint, that it is impossible to define precisely what is meant by this term. This state of affairs makes it also impracticable to dwell on the mechanical problems involved. It is clearly out of the question to analyze the hundred or more articles which have appeared with this name for a subject.

In general, however, it may be said that an external and an internal form of serous meningitis are recognized and that these may be acute or chronic. In the acute external form the cortical pia arachnoid is described as being inflamed and infiltrated with round cells or leukocytes with serous exudation into the subarachnoid space and its prolongations. Sometimes the adjacent brain tissue is inflamed and edematous. When chronic, the pia may or may not be described as thickened. In the internal form there is transudation into the rentricles with dilatation. Quincke and others ${ }^{62}$ hare described the fluid as clear. Boenninghaus ${ }^{63}$ believes that acute idiopathic hydrocephalus follows acute serous meningitis, while Thiemich" apparently considers that the "so-called acute hydrocephalus of childhood" and "ventricular serous meningitis" are identical.

Both Boenninghaus and Quincke have noted that non-inflammatory collections of fluid in the pia-arachnoid space are easy to mistake for serous meningitis. These pial effusions were discussed by Huguenin many years previously. He noted their association with certain atrophic states of the brain. I consider that knowledge of the subject has not greatly advanced since Huguenin's time.

Of late years much attention has been given to the abnormally large collections of fluid so often seen beneath the arachnoid membrane in

56. Avellis, G.: Oertliche Serosa Meningitis bei akuter Keilbeineiterung mit Spontanheilung, Verhandl. d. Ver. siid-deutsch. Laryngol., 1907, 454. 1859 .

57. Riebold, G.: Ueber serosa Meningitis, Deutsch. med. Wchnschr., 1906, xxxii,

58. Thiemich, M.: Serous Meningitis in Diseases of Children, Pfaundler and Schlossman, Eng. Trans., 1908, iv, 376.

59. Paradis, A.: Ueber Meningitis serosa, B. George, Leipsic, 1906, p. 26.

60. Axhausen, G.: Zur Kenntniss der Meningitis serösa acuta, Berl. klin. Wehnschr., 1909, xlvi, 244.

61. Williams, L.: Serous Apoplexy, Med. Press and Circular, 1906, Ixxxi, 499.

62. Thiemich (Serous Meningitis in Diseases of Children, p. 413) considers that the fluid of internal serous meningitis is usually clear but that there are slight changes which indicate inflammation of the chorioid plexus and ependyma.

63. Boenninghaus: Die Meningitis serosa acuta, p. 93.

64. Thiemich: Serous Meningitis, in Diseases of Children, p. 415. 
subjects that have died of chronic alcoholism. It was primarily with the purpose of shedding some light on this subject that my paper was begun.

It became clear to me that post-mortem examinations of the brain alone would never throw sufficient light on the causation of these accumulations of fluid. I determined therefore to approach the subject by the following methods:

1. By means of an analysis of a series of cases, to show the frequency of association of pial edema with various diseases and to determine the influence of other factors such as age and nutrition.

2. By a consideration of the physical phenomena underlying the accumulation of fluid in the cranial cavity.

3 . To determine whether there were any chemical differences in the cerebrospinal fluids in these various conditions that might indicate their etiological relation.

4. By the estimation and comparison of brain weights or volumes and cranial capacities in a series of cases.

With this brief introduction $I$ now proceed to describe my observations.

PART I: ANALYSES OH CASES ACCORDING TO AGE, NUTRITION AND
DISEASE

Pial edema is a very common condition at autopsy, for out of a totai of the 665 cases which form the basis of this report, it was recorded 375 times, a percentage of 56.4 .

The cases with pial edema (375) have been placed in one group, those without pial edema in another.

$\mathrm{AGE}$

An examination of the appended table shows: First, a relative frequency of pial effusion in infants from 4 months to 5 years of age. ${ }^{65}$

Second, an entire absence of this condition between the ages of 6 and 15 years, followed by a rapid increase that culminates between the thirtyfifth and fortieth years with later a more gradual increase that reaches the maximum at from 80 to 85 years (old age).

The youngest subject with pial edema was 4 months old. When it is observed that in this series there were fully thirty-one cases of children, between birth and the fourth month, with dry pias, this initial date mar not be without some significance. ${ }^{\theta 6}$ The absence of pial edema in nine subjects between 6 and 15 is also significant. ${ }^{67}$

65. Eighty-two infants were examined: of these eighteen presented pial effusion, that is 21.9 per cent. of the total number of cases.

66. The ages of the thirty-one children mentioned above were as follows: 13 hours, 20 hours, 21/2 days, 13 days, 21 days, 1 month (three cases), 6 weeks (two cases), 7 weeks, 2 months (nine cases), 9 weeks, 10 weeks, 3 months (nine cases).

67. A case of marked pial edema in a boy of 15 who died of juvenile paresi= was observed subsequently. In this case the brain shrinkage is readily explainable on pathological grounds. 
In the examination of fourteen cadavers between the ages of 16 and 20 years, pial edema was found twice, or in $14 . .2$ per cent.

In an examination of thirty-four cadavers between the ages of 21 and 25, 26.4 per cent. presented pial edema. Of the nine, five showed a slight degree, three a moderate degree including one case of alcoholism, and one a marked degree (a case of cerebral syphilis).

In forty-five subjects between the ages of 26 and 30 years, 51.1 per cent., or twenty-three presentcd pial edema: five slight, nine moderate (including two alcoholics) and nine marked cases. It is important to note that in the nine marked cases, six subjects had lesions usually accompanied by brain shrinkage.

In sixty-four cases between the ages of 31 and 35 years, forty cases showed pial edema, twenty moderate, twelve marked, and one extreme

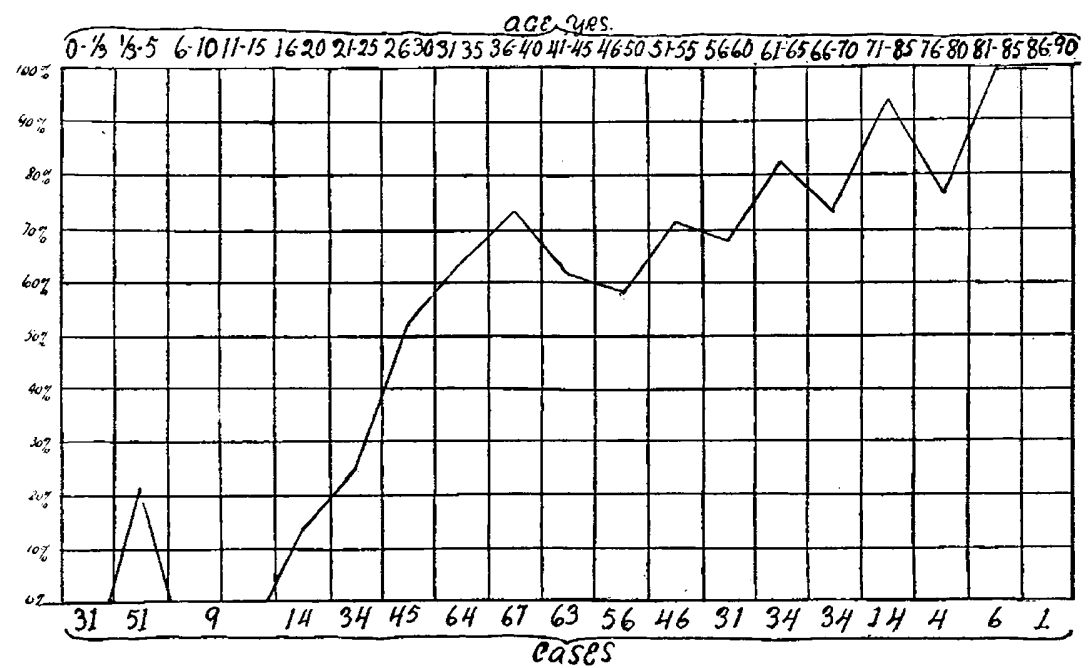

Fig. 1.-Chart, compiled from 604 cases, showing relative frequency of pial edema at various ages.

(including eight alcoholics and one case of insanity). The cause of death in the "extreme" case could not be determined.

In sixty-three subjects between the ages of 41 and 45 years, 61.9 per cent, or forty-one showed pial edema ; twenty-one of moderate, eleven of marked and two of extreme grade, including in all six alcoholics.

In fifty-six subjects between the ages of 46 and 50 years, 58.9 per cent., or thirty-three, showed pial edema; twelve of moderate and eighteen of marked grade, including four alcoholics.

In forty-six subjects between the ages of 51 and 55 years, 71.7 per cent., or thirty-three, showed pial edema; thirteen moderate, seventeen marked, one extreme (pulmonary tuberculosis). This group included two cases of chronic alcoholism and one of insanity. 
In thirty-one subjects between the ages of 56 and 60 years, twentyone, or 67.7 per cent., showed pial edema; eight moderate, nine markerl and one extreme.

In thirty-four cadavers between the ages of 61 and $65,82.5$ per cent., or twenty-eight, showed pial edema; nine moderate, eleven marked and three extreme cases; one case of alcoholism.

In fourteen subjects between the ages of 71 and 75 years, 92.8 per cent., or thirteen, showed pial edema; six moderately and four markedly.

The four subjects between the ages of 76 and 80 years, 75 per cent., or three, showed pial edema, all markedly. The brain of the subject without edema was normal in size and appearance.

In six subjects between 81 and 85 years of age, 100 per cent. showed pial edema; two moderately, two markedly, and two extremely.

There was one subject showing pial edema between the ages of 85 and 90 years.

\section{NOTRITION}

In neither adults or children did there appear to be any definite relation between pial edema and emaciation.

Of 357 cases of pial edema in adults, forty-nine were not fully described as regards nutrition and therefore were subtracted from the general total, leaving 308 cases for analytical purposes. The state of nutrition in these cases of pial edema was as follows:

Fat
Fair to good nutrition $\ldots \ldots \ldots \ldots 168$, or 54 or 4.5 per cent.
Poorly nourished $\ldots \ldots \ldots \ldots \ldots \ldots 4$, or 11 per cent.
Emaciated $\ldots \ldots \ldots \ldots \ldots \ldots \ldots 6$, or 20.7 per cent.
Markedly emaciated $\ldots \ldots \ldots \ldots \ldots 28$, or 9 per cent.

From the above it is seen that pial edema is associated with good nutrition in the majority of instances, (59 per cent. as against 41 per cent. for the badly nourished).

Of the eighteen infants who had pial edema, two were not fully described as regards nutrition. The remaining sixteen presented findings similar to those of the adult series given above. The nutrition in these cases was as follows:

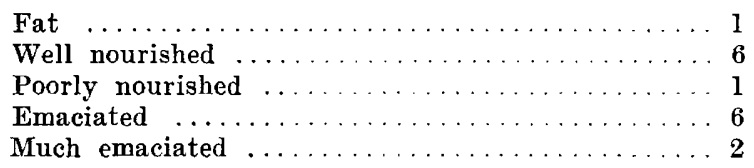

The question whether all poorly nourished people have pial edema is answered by referring to the data concerning the cases in my series with dry pias. In this group cachexia was present ninety-eight times unassociated with any subarachnoidal collections of fluid-a number sufficiently large to show that no relationship exists between the two conditions. 


\section{RELATIONSHIP BETWEEN PIAL AND EDEMA DISEASE PROCESSES ${ }^{68}$}

The records were grouped according to the anatomical diagnosis with a view of determining whether any diseases or conditions were regularly associated with pial edema.

Pial edema is found on the average in practically two out of every three adults at autopsy. In our series of 542 adults, the subjects with pial edema, 355 in number, constituted 65.5 per cent. of the total number. Those without pial edema, 187 in number, comprised 34.5 per cent. of all the subjects.

It is evident that pial edema cannot be assumed to be related to any particular disease process unless it can be shown that it occurs with greater frequency with that disease than it does with other diseases. The simplest method to determine whether such an association exists for any particular disease is to compare the number of subjects which show pial edema with those which do not show pial edema. If the ratio exceed $65.5: 34.5$ (the ratio of our total cases as shown above), such a relationship would be indicated.

The total number of cases of a given disease from both the edema and the no-edema column was set down and the percentages computed. For example, under the heading "Adhesive Pleurisy" I found thirty-one cases associated with pial edema and twenty cases unassociated; the proportion of one to the other expressed in percentages is 64.5 and 35.5 per cent. respectively.

These figures represent the absolute percentages; since the number of cases of pial edema available for study is much larger than the number of cases without pial edema we can determine the relationship which the disease bears to the disease process in question by the use of a method which does away with the necessity of directly contrasting two unequal series. This is accomplished by reckoning percentages in each column (i. e. the pial edema, and the non-edema column) separately and then by comparing the percentages so obtained. The results in each case are found to be independent of the number of cases in either series, as they represent proportions only. Their value consists wholly in their use for purposes of comparison.

Using this method we reckon first the percentage of adhesive pleurisy (thirty-one cases) in the pial edema column (355 cases); this gives us the figure 8.7 per cent. We then similarly reckon the percentage of adhesive pleurisy (twenty cases) to the $18 \tau$ cases of the "control" series which is found to be 10 per cent. These percentages being compared with one another indicate that adhesive pleurisy occurs with about the

68. The tabulated cases on which these statistics are based were so extensive that it was found impracticable to include them in this article. I shall be very glad to submit them to anyone interested. 
same frequency both with and without pial edema, since the proportion of occurrence of the lesion is nearly the same in either series. If now we should find that for any given disease we had a high percentage in the pial edema column, while much lower in the no-edema column, we should infer that the lesion either played some etiological rôle or was at least definitely associated with pial edema. If on the other hand we should find the percentage in the pial edema column level with or below the percentage for the same disease in the other column we should decide that the disease bore no particular relation to pial edema.

It will be at once observed that a negative result is attained when the percentages for a given disease are the same or nearly the same in the pial edema and the control columns.

It was considered best to draw conclusions only where the figures were high enough to lend value to such percentages and for this reason lesions that appeared a few times only on the chart were not emphasized.

As a result of my preliminary studies in children and young people, it seemed wise to omit all cases under maturity from the disease columns, since it is possible that in them certain unexplained factors of development might result in confusion.

Acute Parenchymatous Nephritis.-Reckoning the percentages by the method already explained, I found that acute parenchymatous nephritis was present in 10.9 per cent. of all cases with pial edema, and in 10.6 per cent. of all the cases of the series without pial edema.

Chronic Interstitial Nephritis.-Reckoning the percentages in each column separately, chronic interstitial nephritis was found present in 32.9 per cent. of all cases with pial edema and in 30.4 per cent. of all cases without pial edema. The small granular kidney was present in 18.5 per cent. of all subjects having pial edema and 15.5 per cent. of all subjects without pial edema.

These figures do not indicate any essential relationship between pial edema and this type of kidney lesion. ${ }^{99}$

Taken altogether our figures indicated an absence of association between pial edema and acute or chronic Bright's disease.

Syphilis.--Aside from paresis, which will be referred to again, the figures of the table did not suggest that general syphilitic infection plays a causative rôle.

69. In forty cases with pial edema the microscopical sections showed no trace of any kidney lesion, while in about the same number of cases there were noted only slight or beginning renal changes. It should be noted that the single case of uremia which we had, showed a slight degree of pial edema. There was no moisture of the cut surface apparent to suggest cerebral edema, no flattening of the convolutions or any other sign characteristic of the brains described by Traube. 
Chronic Pulmonary Tuberculosis.-This was present in 16.3 per cent. of all cases of pial edema and in 26.7 per cent. of all cases without pial edema.

Chronic Cardiovalvular Disease.-The figures obtained were 10.9 per cent. with pial edema and 11.7 per cent. without.

General Arteriosclerosis.-The figures obtained were 12.9 per cent. with pial edema and 9.4 per cent. without pial edema. These figures do not suggest a relationship between pial edema and arteriosclerosis.

Anemia.-We had only four cases of anemia. Two of these were associated with pial edema and two were not.

Advanced Alcoholism.-Here was found the first really significant evidence of relationship between pial edema and a disease process. Aitogether there were eighty-nine cases of chronic alcoholism in the series. Of these seventy-two subjects had pial edema, or 80.9 per cent., while the remaining seventeen had dry pias, or 19.4 per cent. Reckoning the percentages for each column separately I found that chronic alcoholism was present in 20.2 per cent. of all our cases with pial edema and present in only 9 per cent. of all cases without pial edema. The frequency with which pial edema occurs in chronic alcoholism is thus represented by the ratio $20.2: 9$, the latter figure being taken to represent the proportion of chronic alcoholics in which no pial edema is present. It may thus be said that pial edema occurs in something like two-thirds of all cases of chronic alcoholism.

Pial Edema Associated with Transudation in Other Parts of the Body. -A. Localized or Generalized Subcutaneous Edema: My tables showed:

1. Localized edema of the subcutaneous tissues occurs apparently without special relation to pial edema.

2. Generalized edema: Anasarca showed a slight preponderance in the pial edema column, but the small number of cases quoted rendered this proportion of little or no value.

3. Ascites: The same thing may be said of ascites as of anasarca.

B. Polyserositis: I had a sufficient number of cases (forty-four) to warrant me in drawing conclusions from the percentages obtained. The percentage of serositis cases was slightly higher in the control column ( 20 per cent.) than in the pial edema column (18 per cent). We therefore concluded that polyserositis is not associated with pial edema regularly and that it does not have necessarily the same causative factors.

Condition Associated with Acute Toxemia.-I had 466 cases which were considered as belonging in this category; 304 of these presented pial edema; the remaining 162 were not associated with this condition.

Reckoning the percentages of each series as already explained, I found acute toxemia in some form present in 85 per cent. of all cases that had no pial edema. 
Conditions Associated with Bacteriemia.-There were 191 cases that could properly be grouped under the heading of bacteriemia; 111 of these presented pial edema, the remaining eighty had no pial effusion. I thus found bacteriemia present in 31 per cent. of all our cases of pial edema, and present in 42 per cent. of cases without pial edema.

Chronic Inflammatory Lesions in the Serous Cavities.-I had altogether 104 cases that were included under this heading $;^{70}$ sixty-four of these showed pial edema, while forty were unassociated with pial edema.

Chronic inflammation of the serous cavities was thus present in 18 per cent. of the cases of pial edema and present in 21.3 per cent. of the cases without pial edema.

Chronic Gastritis.-This condition was present in 13.2 per cent. of the cases with edema of the pia and in 13.9 per cent. of the cases which did not present pial edema.

Malignant Tumors.-The figures for these cases disclose nothing of significance.

Status Lymphaticus.-Of the fifteen cases of status Iymphaticus in our series, twelve brains were large enough to completely fill the skull cavity. Pial edema was present in only three.

From the considerable proportion of large or fully developed brains noted with status lymphaticus, it might be inferred that we had here to do with a brain hypertrophy similar to that indicated by Anton ${ }^{71}$ and described by Bartel" in some of his "status" cases. Such an inference should not receive undue emphasis; first, because complete weight records are not available in our series, and, second, because a large proportion of our subjects happened to be young people in whom brain volume is usually considerable.

Insanity.-The psychopathic cases, most important because of the possibility of organic changes being present, were too few in number for comparative figures.

\section{SUMMARY}

Age.-Edema of the pia was not found in my series before the fourth month. It occurred with moderate frequency from the fourth month to the fifth year. Between the fifth and sixteenth years it was absent. Beginning with the sixteenth year it rapidly increased in frequency to the period between the thirty-sixth and fortieth years, ${ }^{73}$ when, following a slight sharp decline, it continued to increase though less rapidly throughout the later periods of life, becoming universal in old age.

70: Cases of serositis not included in this summary.

71. Anton: Wahre Hypertrophie des Gehirns mit Befunden von Thymusdrüsen und Nebennieren, Wien. klin. Wchnschr., 1902, xv, 132.

72. Bartel, Julius: Ueber die hypoplastische Konstitution und ihre Bedeutung, Wien. klin. Wchnschr., 1908, xxi, 783.

73. A time of life in which there is a very high death-rate among alcololics. 
Nutrition.-Pial edema occurs independently of changes in the nutrition of the body.

Discase Conditions.-1. Pial edema does not appear to bear any particular relationship to the following common conditions: chronic nephritis; chronic pulmonary tuberculosis; chronic cardiovalvular disease; acute toxemia; bacteriemia; chronic inflammatory lesions in the serous carities, and chronic gastritis.

2. Pial edema is definitely associated with chronic alcoholism. occurring in more than two-thirds of all cases.

3. There were too few cases of syphilis, anemia and insanity to permit me to form conclusions in regard to these cases.

In conclusion I wish to emphasize, first, the progressive increase of pial edema after puberty; second, the absence of any relationship between pial edema and nutritional changes in the body at large; third, the negative findings as to association between pial edema and the general disease processes studied, except alcoholism.

PART 2. THE MECHANICS AND CHEMISTRY OF THE SPIXAL FLLID AXD THE ANATOMY AND PHYSIOLOGY OF THE MEMBRAXES

Having determined the relationship which pial edema bears to most of the important diseases, we are now in a position to study the character of the fluid present in this condition.

\section{YORMAL DISTRTBUTION OF CEREBROSPINAL FLUID}

The cerebrospinal fluid is present within the confines of the subarachnoid space, the ventricles of the brain, the perivascular spaces and the central canal of the spinal cord. It is limited externally by the arachnoid membrane (external to which, over the cortex, lies the subdural space) and internally by the pia.

\section{DISTRIBUTION OF THE FLEID IN PIAL EDEMA}

In pial edema we find that the distribution of the fluid is the same as above stated, but that it is greatly increased in amount. The peculiarities as regards localization are as follows:

1. It is constantly found on the superior surface of the cerebral hemispheres, especially over the vertex.

2. It is found on the superior surfaces of the frontal lobes in relatively less amount.

3. The anterior and posterior cisterna are distended.

4. It is found often as bleb-like accumulations on the posterior and inner margins and on the superior surfaces of the cerebellar hemispheres.

5. There is occasionally a similar accumulation on the anterior poles of the temporosphenoidal lobes. 
6. There is occasionally an apparent increase of fluid in the perivascular spaces.

$\%$. There is occasionally considerable moisture of the brain tissue.

8. There is occasionally increase of fluid in the subarachnoid space of the cord.

9. Usually there is an increase of fluid in the lateral ventricles.

10. It is rare to see any increase over the lateral regions of the cerebral cortex.

No increase of fluid has ever been observed by me in the following places:

A. The under surface of the frontal lobes.

B. The under surface of the temporosphenoidal lobes.

C. The inner surface of the cerebral hemispheres.

We thus observe a general tendency on the part of the excess fluid to occupy a position above that of the brain tissue proper.

\section{THE APPARENT SIGNIFICANCE OF THIS DISTRIBUTION}

The localization of the fluid as given above is in marked contrast to that of the exudate in most cases of suppurative meningitis, especially in the epidemic type. As is well known, in most cases of meningitis the exudate is found chiefly at the base-a phenomenon that is especially noticeable in tuberculous and epidemic meningitis. The experience of this laboratory is fully in accord with the above statement and points to a tendency on the part of inflammatory changes in the meninges either to begin at the base and spread thence over the cortex, or to remain localized at the base. ${ }^{74}$

The above localization of the fluid of pial edema is in itself suggestive of the action of gravity-and it is the one which the fluid would take were there any additional room within the cranial cavity, for the reason that as the specific gravity of the brain (1.038) is greater than that of the fluid in which it lies (1.002-1.010), the brain then would naturally seek a dependent position, forcing the fluid to a higher level.

The presence of the fluid in the cisternæ pontis (ant. subarachnoidean space) has already been mentioned.

In performing an autopsy, however, some care is necessary in order to see the fluid in situ; for although the arachnoid at these points is normally somewhat thicker, it is at the same time unsupported and thus is readily torn when the brain is lifted up, allowing its contents to drain away into the cranium.

When the anterior subarachnoid space is ruptured, the fluid from the posterior immediately drains across the cruræ cerebelli and thence into the skull cavity.

74. For a consideration of this subject dealing with meningitis, $I$ would refer the reader to the recent article by W. J. Elser and F. M. Hunton; Studies in Meningitis, Jour. Med. Research, 1909, xx, 371. 
To what degree evacuation of the lateral ventricles follows this draining through rupture of the cisternæ is difficult to say, but that it is relatively slow there is every reason to believe.

The evacuation of the fluid over the cortex after removal of the brain also takes place gradually, apparently because the septa of the subarachnoidean chambers offer a partial obstruction to the flow of the fluid. In some cases the arachnoid reveals an almost gelatinous mass but possibly this may be due to clotting of the fluid after removal.

That the fluid over the cortex is enmeshed is shown by the following facts:

1. The fluid over the cortex may remain in situ some time after the brain is removed.

2. Puncturing the dependent areas over the cortex sometimes results in the evacuation of only a small area about the site of the puncture. To illustrate this fact we may cite the following:

CASE 1879.-Pia arachnoid moderately distended with clear slightly yellowish fluid, most marked over the convexity. A small puncture (about $5 \mathrm{~mm}$. in diameter) was made over one of the sulci, the probe passed down through some watery and slightly gelatinous tissue to the cortex. The fluid about this puncture drained away leaving a depressed area $1 \mathrm{~cm}$. in diameter, but the fluid beyond this area was apparently unaffected at the end of an hour.

The best way to maintain the cisternæ intact, according to my experience, has been to insert the calvarium hook beneath the occipital protuberance and tear off the calvarium from below upward, instead of from above downward (the usual practice). The dura being then cut away, the frontal lobes can be lifted up disclosing the cisternæ unruptured.

The pathologist has usually considered that an excessive amount of fluid at the base and the distention of the cisternæ was an indication of an increased or high intracranial tension during life. Although it may be granted that this is the explanation for a large number of cases, we must not forget that it is not conclusive evidence. The fallacy of conclusions based on such evidence is well illustrated by the conclusion drawn by the ancient Greeks on post-mortem evidence alone that the aorta contained blood mixed with air.

\section{THICKENINGS OF THE ARACHNOID}

In a considerable number of all pial edema cases there is a greater or less degree of opacity and thickening of the meninges. Sometimes this is chiefly limited to the area over the superior surface of the cortex along the longitudinal sinus; again it is found orer cortex and cerebellum, and occasionally it has an even more generalized distribution. 
In every case examined by me this opacity was found to be due to connective tissue thickening of the arachnoid, involving slightly the piaarachnoid trabeculæ, the pia itself showing no change.

This lesion consists of a proliferation of the fixed connective tissue elements without exudation or vascular changes.

That a process of this essentially proliferative character arising at a distance from the blood-vessels ${ }^{75}$ should be the cause of the large fluid aceumulations seems hardly possible.

\section{CHEMISTRY OF FLUID IN PIAL EDEMA}

The final determination as to the inflammatory or non-inflammatory character of the fluid rests in the last analysis with the chemical examination. It is a well-known fact that fluid collected after death is worthless for examination, since post-mortem changes render chemical tests of doubtful value. ${ }^{76}$ The most satisfactory method is to collect the fluids intra vitam and to verify the findings thus obtained at autopsies. Such procedure, naturally, is attended with many disappointments.

With the exception of one case reported by Dufour, ${ }^{77} \mathrm{I}$ have so far been unable to find in the literature any satisfactory record of analyses of spinal fluid from subjects of "wet-brain." A specific test for serum albumin or globulin rather than for protein should be of value in determining the question of possible inflammatory influences. Serum albumin is not a normal constituent of cerebrospinal fluid ${ }^{78}$ and therefore its presence in the class of cases under discussion should indicate an exudative or transudative process. The absence of traces of serum albumin, in the light of our present knowledge of the secretory origin of the cerebrospinal fluid, would therefore indicate that the spinal fluid is the product of normal secretion. Professor Hastings has kindly supplied me with a series of analyses on this class of cases, and these will now be considered. ${ }^{79}$

A spinal fluid from a subject of alcoholic "wet-brain" examined by him showed a protein content of 0.005 per cent., a minimum normal figure.

The figure for protein quoted above speaks strongly against the presence of either transudate or exudate in the spinal fluid of these cases. Professor Hastings analyzed several other specimens of alcoholic "wetbrain" without reference to the protein content.

75. The blood-vessels lie close to the pia.

76. Myers, V. C.: The Cerebrospinal Fluid in Certain Forms of Insanity with Special Reference to the Content of Potassium, Jour. Biol. Chem., 1909, vi, 115.

77. Dufour, H.: Cytologie du liquide céphalo-rachidien dans un cas de méningite chronique alcoolique, Bull. et mém. Soc. mêd. d. hôp. de Paris, 1901, xviii, 1035 .

78. Halliburton in Kirke's Physiology, Ed. 1908, p. 178.

79. Spinal Fluid Analyses in Alcoholic Wet Brain Cases, loaned by Professor Hastings of Cornell University. 
The amounts in these cases ranged from 25 to 88 c.c.; all specimens were clear, sterile and free from coagulum or sediment. The cytological count was as given in Table 1.

TABLE 1.-CELL-COUNT-100 FIELDS

$\begin{array}{ccccc}\text { Case } & \text { Polys. } & \text { Small Monos. } & \text { Endothelial Cells } & \text { N. B. Cs. } \\ 1 & 0 & 2 & 0 & 12 \\ 2 & 0 & 7 & 1 & 18 \\ 3 & 0 & 6 & 0 & 27 \\ 4 & 0 & 1 & 2 & 1,456^{*} \\ 5 & 0 & 1 & 0 & 0 \\ 6 & 0 & 3 & 0 & 0 \\ 7 & 0 & 1 & 0 & 1 \\ 8 & 0 & 0 & 0 & 0\end{array}$

* First-tube contaminated with blood.

The conclusions from these analyses were that the fluid of alcoholic "wet-brain" did not differ from normal cerebrospinal fluid.

\section{CIRCOLATORY CHANGES IN THE MEMBRANES WITH PIAL EDEMA}

It is well known that it is difficult to determine from post-mortem findings the circulatory conditions which were present during life in cases of pial edema, since alterations in the vascular system of the brain occur frequently just prior to and at the time of death.

My findings in regard to the condition of the meningeal circulation in pial edema (from post-mortem study of 100 cases) are as follows:

Cases

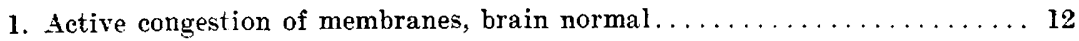

2. Passive congestion of membranes, brain normal.............. 21

3. Active and passive congestion of membranes, occurring together, brain

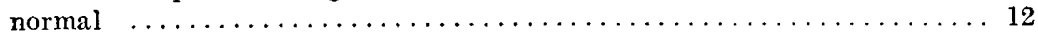

4. Active congestion of membranes with anemia of brain $\ldots \ldots \ldots \ldots \ldots \ldots$.

5. Passive congestion of membranes, with anemia of brain $\ldots \ldots \ldots \ldots \ldots \ldots 1$

6. Active congestion of membranes and brain $\ldots \ldots \ldots \ldots \ldots \ldots \ldots \ldots \ldots \ldots$

7. Passive congestion of membranes and brain $\ldots \ldots \ldots \ldots \ldots \ldots \ldots \ldots, \ldots \ldots$

8. Active and passive congestion of membranes and brain $\ldots \ldots \ldots \ldots \ldots \ldots$

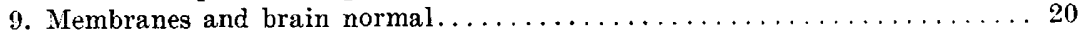

10. Pia-arachnoid normal, brain anemic .................... 4

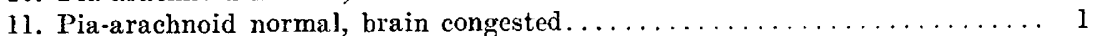

12. Anemia of brain and membranes................... 6

The commonest condition found was thus passive congestion of the membranes (present in 21 per cent.). The next most common was an apparently normal condition of the vessels of the brain and meninges ( 20 per cent.). Active congestion of the membranes and a condition of active and passive congestion of the membranes, occurred in 12 per cent. Anemia of the membranes and brain was present in 6 per cent. Altogether passive congestion of the membranes (either alone or combined) occurred in fifty-one cases ( 51 per cent.), whereas active congestion was 
present in only forty cases ( 40 per cent.). The preponderance of passive congestions in this series agrees with the statement of Kaufmann ${ }^{80}$ that most of the cerebral congestions observed at autopsy are of the passive type.

The frequent occurrence of passive congestion can hardly be taken as an indication that passive congestion has any special influence in the production of pial edema because there is nothing to show that it is more common with pial edema than with the general run of autopsy cases. Furthermore, the wide variety of other rascular conditions cited in this series shows that pial edema bears no constant relation to any particular circulatory condition as seen at autopsy.

\section{P.ART 3. THE PHYSICS AXD IECHANICS OF PIAL EDEMA}

$\mathrm{Mr}$ observations thus far have been with a view to determine under what conditions pial edema is found. Let us now consider from a more theoretical standpoint the mechanics involved in the causation of accumulations of fluid in the pia-arachnoid. Two hypotheses present themselves:

1. The accumulation of fluid is the result of an increase of secretory activity of the chorioid plexus, or a lack of resorption, leading to a compression of the brain substance, or

2. The finid has simply collected as a result of some undetermined process leading to a reduction in size of the brain.

The first hypothesis to be discussed is whether the fluid can actually compress the brain so as to give rise to the appearances met with in pial edema.

Before doing so, however, we must review certain well-established mechanical principles, a correct understanding of which is essential to a comprehension of some of the more complex problems in connection with pial or cerebral edema and serous meningitis.

It will not be necessary to sketch the outlines of the study of intracranial mechanics since the time of the second Monro. ${ }^{81}$ Let me present only the points that are inrolved and endeavor briefly to show their bearing on our subject.

Of fundamental importance is the old question "Is the craniospinal canal independent of the influence of atmospheric pressure?"

Certain early writers, as Monro, Kellie, ${ }^{82}$ Abercrombie and Reid, ${ }^{83}$ and nearly all modern writers, among whom may be included Naunyn

80. Kaufmann, Eduard: Lehrbuch der speziellen pathologischen Anatomie, Berlin, 1904, p. 983.

81. Monro, Alexander: Observations on the Structure and Functions of the Nervous System, Edinburgh, 1783.

82. Kellie, George: Reflections on the Pathology of the Brain. Tr. Med.-Chir. Soc. Edinburgh, 1824, i, 84.

83. Peid: Physiol, Anat. and Path. Researches, xxv. 
and Schrieber, ${ }^{84}$ Falkenheim and Taunyn, ${ }^{85}$ Horsley and Spencer, ${ }^{86}$ Horsley, ${ }^{\text {s7 }}$ Spencer, ${ }^{88}$ Roy and Sherrington, ${ }^{89}$ Hill, ${ }^{90}$ Kocher, ${ }^{91}$ Cushing ${ }^{92}$ and many others, have decided that it is.

The earlier negative conclusions of Burrows ${ }^{93}$ and Donders ${ }^{94}$ were seriously considered for over half a century after their promulgation.90

Leonard Hill's argument in favor of the absence of atmospheric pressure within the skull cavity was as follows:

If the spinal cord of a dog be divided or the splanchnic nerves be cut and the animal be placed in the vertical feet-down position, the blood-pressure in the brain will under the influence of gravity, fall to zero. If the skull be now trephiner, and the dura be rapidly opened, the brain, which was before in close apposition with the dura, may now be seen collapsing under one's very eyes, as it is emptied of blood by atmospheric pressure. ${ }^{96}$

Additional evidence in confirmation of Leonard Hill's view that atmospheric pressure was absent in the skull cavity was obtained by the following experiments:

Experiment 1.-A trocar was introduced into the spinal canal of a prone intact cadaver and a small amount of fluid ran out owing to persistence of the pressure existing during life. No more escaping, suction was applied by means of a syringe and a little more fluid was obtained (altogether about 3 c.c.). The trocar was then removed and the calvarium opened. The eisternæ contained the usual amount of fluid and likewise the spinal canal.

84. Naunyn, B., and Schrieber, J.: Ueber Gehirndruck, Arch. f. exper. Path. i. Pharmakol., 1881, xiv, 1 .

85. Falkenheim, H. and Naunyn, B.: Ueber Hirndruck, Arch. f. exper. Path. u. Pharmakol., 1887, xxii, 261.

86. Horsley, V., and Spencer, W.: Phil. Tr., 1891,

87. Horsley, Sir Victor: The Mode of Death in Cerebral Compression and Its Prevention, Quart. Med. Jour. London, I894, ii, 305; The Structure and Functions of the Brain and Spinal Cord, P. Blakiston's Son \& Co., Phila., 1892.

88. Spencer, W.: The Central Nervous Mechanism of the Respiration, Arris and Gale Lectures, Lancet, London, 1895, xxxi, 532.

89. Roy, C. S., and Sherrington, C. S.: On the Regulation of the Blood Supply of the Brain, Jour. Physiol., 1890, xi, 85.

90. Hill, Leonard: The Physiology and Pathology of the Cerebral Circulation, London, 1896, Churchill.

91. Kocher, T.: Hirnerschütterung, etc. Specielle Pathologie und Therapie in Nothnagel, Wien, 1901, Ed. 2, Part, 3, ix.

92. Cushing, H.: Some Experimental Clinical Observations Concerning States of Increased Intracranial Tension (Mutter Lecture), Am. Jour. Med. Sc., 1902, cxxiv, 375; The Blood Pressure Reaction of Acute Cerebral Compression, etc., Am. Jour. Med. Sc., 1903, cxxv, 1017; A Discussion of Some Remote Effects of Cranial Injuries, etc., New York Med. Jour., 1907, lxxxv, 97, 61, 208.

93. Burrows, George: Disorder's of the Cerebral Circulation and on the Connection Between Affections of the Brain and Diseases of the Heart, Philadelphia, 1848, Lea and Blanchard.

94. Donders, F. C.: Nederl. Lancet, 1850.

95. Reynolds and Bastian: (ongestion of the Brain, in Reynolds' System of Medicine, 1879.

96. Hill, Leonard: The Physiology and Pathology of Cerebral Circulation, p. 36. 
Exprnmext 2.-Calvarium removed first. Cisternæ intact and seen to be full of clear fluid. Spinal puncture; 12 c.c. fluid came through cannula as if under slight pressure. Cisternæ re-examined and found full as before. Brain covered witl wet cloths; in ten minutes fluid at the base had all disappeared into the cord.

The isst experiment shows that outside air-pressure does not influence the contents of the craniospinal canal, since it was impossible to evacuate the fluid (except that in excess, and a slight amount in addition, due, possibly, to the stretching inward of the spinal membranes) through the single opening.

When, however, as in Experiment 2, a second opening was made and outside air-pressure admitted, there was no obstacle to the ready eracuation of the fluid in the direction of gravity.

The principle involved in these experiments is very easy to demonstrate with suitable apparatus. It will be observed that the fluid in the craniospinal canal in the first case has behaved as might be expected were atmospheric pressure absent.

There are certain anatomical features that require consideration in this connection.

Figure 2 represents the craniospinal canal, to all intents and purposes a closed cavity; the heavy black line its bony confines; the thinner line within represents the arachnoid which determines the outer limit of spinal fluid. While this membrane is not actually adherent to the overlying dura and bony walls, it lies in close apposition within the skull and is therefore incapable of any distention outward. In the spinal canal, lowever, it (together with the dura) lies like a sac at some distance from the bony walls, being separated from these walls by loose and compressible areolar tissue containing a plexus of veins. ${ }^{97}$

Any increase of fluid within such a cavity must find room through distention of the sac outward. ${ }^{98}$

97. Schafer, E. A.: In Quain's Anatomy; Spinal Cord and Brain, Part 1, p. 3, Longmans, Green and Co., London, 1893.

98. The suggestion that the theca vertebralis plays a part during life in the accommodation of excessive amounts of spinal fluid and the production of high intracranial pressure will doubtless arouse opposition among those who have demonstrated vascular relationship to pressure phenomena. I do not, however, disagree with Dr. Ferrier's statement that under normal conditions the ebb and flow between the cranial and spinal cavities is so small as to be practically a neg. ligible quantity, but I desire to point out that no experimental work so far done is of much value in helping us to reach conclusions in the present work: largely because of the fact that none of these experiments has been arranged so as to show what mechanical changes take place when resorption of spinal fluid is prevented and when the high pressure is caused by an excessive amount of the fluid itself. My suggestion that distention of the theca is a factor is based on a study of the behavior of fluids within the craniospinal canals of cadavers. The distensibility of the sac under these circumstances has long ago been demonstrated, but Dean (Jour. Path. and Bacteriol., 1893, i, 28) and others have been inclined to doubt whether such a process could take place in living subjects.

It is of course unlikely that such a process would take place unless there were some hindrance to resorption. 
It will be readily seen that while fluid can, at the outset, be forced into this sac without greatly raising intracranial pressure, after an amount has been forced in sufficient to crowd the tissue of the surrounding space and stretch the membranes considerably, there will be an everincreasing resistance for each cubic centimeter forced in, until finally a point is reached at which no more fluid can be introduced, owing to the surrounding tissues having reached their limit of compressibility. It is the elastic recoil of these membranes which are put on the stretch, and the adjacent tissues which are compressed that, to a certain extent, gives the measure of intracranial tension, and thus when a cannula is introduced into this distended sac the tension of the tissues and membranes causes the expulsion of excess of all fluid, until the pressure is relieved.

Not all of the fluid, however, drains away, for a certain amount is necessary to fill various areas in and about the brain substance and the spinal cord. In the skull cavity the amount of this fluid scarcely varies

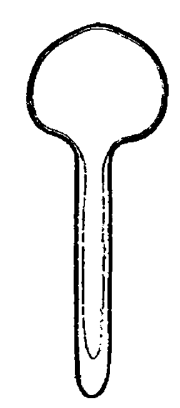

Fig. 2.-Diagram of craniospinal canal; heavy black line, bony confines; thinner line within, the arachnoid which determines the outer limit of spinal fluid.

since it cannot increase against the bony walls, nor can it diminish in amount anywhere without producing a vacuum at that point.

In the canal, on the other hand, the sac will retain only sufficient fluid to maintain equilibrium; that is to say, although a slight excess positive pressure is normally maintained, enough fluid will run out of a cannula to reduce this slight positive pressure to zero. Zero does not mean absence of fluid, but merely that the pressure within the spinal canal has dropped to the normal air-pressure.

Having considered the relation of atmospheric pressure to the skull cavity, and obtained some idea as to the relationship which exists between the membranes and the phenomena of intracranial tension, we may now go a step further and attempt to determine the effect of the factors just discussed on the brain itself. The difficulties involved in a study of this phase of our problem are all the greater when we realize that we know very little about two essential factors, i. e., first, the density or compres- 
sibility of brain tissue and second, the permeability of the brain to fluids under pressure.

Our task now is to determine whether, according to the laws of physics and hydraulics, it would be possible for the brain (its blood-vessels excepted) to suffer compression through general increase of intracranial pressure.

The subject of compressibility must first be considered. Compression, broadly speaking, is brought about through expression of content. It is true that molecules are very slightly compressible, but, as indicated below, ${ }^{99}$ reduction in size from molecular compression would be so insignificant as to deserve but little attention.

For example, take a dry sponge; it is readily compressed in the hand through expulsion of the air molecules from its chambers. On being allowed to soak up water it gains in size and weight but still remains compressible through the ready loss of the water under pressure. If the same saturated sponge be now placed in an air-tight rubber bag which fits snugly at all points, compression is no longer possible, since there is now no longer any means of escape for its fluid contents.

The same principle applies to all homogeneous semifluid bodies; compression takes place by expression of air or fluid content where possible but when air or fluid cannot be expressed the body is termed incompressible.

Since, then, compression sufficient to be visible can only take place through expression of content, it is only fair to inquire whether such compression could occur within the skull cavity. An attempt to force fluid into a receptacle already filled with a solid or fluid would not result in an increase in the amount within the receptacle, but its molecules would simply transmit the added pressure to the walls and there is no reason to assume that the brain is to be looked on as an exception to this physical principle. Compression cannot take place without corresponding allowance being made for the displaced substance in the enclosing medium. Lacking this allowance any reduction of size is impossible.

A converse process, i. e., brain swelling, requires a corresponding displacement of content that is under ordinary circumstances allowed for by the evacuation of spinal fluid-a process that takes place when tension is somewhat raised.

While there is, according to the above explanation, no ground for the belief that general high intracranial pressure could bring about visible changes in the size or contour of the brain, it is barely possible that pressure may be a factor in inducing molecular compression, for although such molecular compression as might result from those degrees of intra-

99. Water, which is relatively incompressible, has increased in weight only about 0.03 pound to the cubic foot at a depth of 350 feet. Treatise on Hydraulics, Merriman. 1906. p. 11. 
cranial pressure that have been registered clinically are very slight when judged from the standpoint of the physicist, still so sensitive a tissue as the nerve cell is known to be, might appreciate the very small increases of molecular densities brouglit about in this manner.

We are not, however, justified in speculating on the chances of molecular compression within the brain until more is known about the compressibility of gray matter; if, for instance, this is slight, pressure would be transmitted through the brain to the surrounding bony confines, the intervening cells of the gray matter being but little affected. On the other hand, were the compressibility greater, pressure would not be so readily transmitted and a slight amount of molecular compression would doubtless result.

The influence of pressure from general causes has already been pointed out; we may now briefly contrast with these the effects of pressure due to local conditions, namely, those caused by hemorrhage or due to tumor growth.

The multiplication of tumor cells exerts, as in other organs, its first effect locally-namely, in compression and pressure-atrophy of the adjacent tissues and in compression of the adjacent vascular structures in the brain. Further compensation for any increase in growth or hemorrhage develops at the expense of the spinal fluid, which is resorbed, while when intracranial tension exceeds that in the venous structures the latter become somewhat compressed. ${ }^{100}$

Striking post-mortem evidence of compression through any intracranial growth is seen in the marked flattening of one or both hemispheres, the dry pia and the marked diminution in amount of blood found in the pial ressels.

For these reasons I believe that compression of the brain by the fluid in cases showing pial edema is an impossibility, and that the appearances observed in cases of pial edema are not attributable to the pressure of the fiuid. These appearances are thus the result of some other agency, in all probability they represent a redistribution or replacement process.

\section{PART 4-PHYSICS AND MECHANICS OF PIAL EDEMA}

For the purpose of determining whether or not I had to deal with a replacement process, I began the rather elaborate system of post-mortem observations which are now to be described.

The cases on which these observations were made were taken from the general autopsy service of Bellevue Hospital. The technic was as follows:

100. The subject of the effects of pressure on the vascular structures within the skull has received so much attention of late that elaboration in this paper would seem superfluous. The following contributions are especially important: Ferrier, David: The Harveian Oration on the Heart and Nervous System, Lancet, London, 1902, ii, 1099; Cushing, H.: ibid. 


\section{TECHNIC}

When possible the calvarium was removed before the thorax was opened in order to prevent a redistribution of the blood. Many times, however, it was impracticable to halt the general autopsy work for this rather considerable interval and the result was that when the thorax was opened and the large veins were cut, as soon as the calvarium was opened and the relative negative pressure within the skull cavity removed, a considerable amount of blood would drain into the thorax from the vessels of the head.

The chief effect of this loss of blood was a reduction in the volume of the brain, causing a discrepancy between the volume of the cranial cavity as afterward registered and the total measured cranial content. The influence of this factor on the weight, specific gravity and volume of the brain, however, need not be considered, as when the blood was not evacuated into the thorax, it would be lost as the brain was being removed, and thus would not enter into subsequent computations.

As soon as the calvarium was removed, a pan was placed beneath to catch the drippings, and the tentorium carefully cut away and laid aside. The hemispheres were gently pushed apart along the great longitudinal furrow, and a small incision made through the corpus callosum into each lateral ventricle, the contents of which were withdrawn by a pipette and measured.

The brain was then removed and allowed to drip into a pan until the watery fluid over the cortex and elsewhere, had quite disappeared. It was then weighed in the air and its weight recorded. Following this it was weighed in water at $15 \mathrm{C}$. with the same balance and its specific gravity computed.

It is important to note here that considerable variation in specific gravity was unavoidable owing to the fact that in many of the brains it was impossible to get rid of all the spinal fluid which was retained in pockets and corners of the sulci. This increased the weight in air, but not in water, and as a very few grams weight will make quite a wide variation in specific gravity, it will be seen that I was here often confronted with an important source of error.

The brain proper having been disposed of, the drippings, the free fluid in the calvarium, and the ventricular fluid, were carefully collected and measured.

The portions of dura cut away were measured in water giving the number of cubic centimeters displaced, and, finally, the capacity of the skull cavity was measured by means of dried peas.

By the addition of the total fluid content of the calvarium with the dura and the brain volume (in c.c.), a fairly accurate estimate of the total cranial content is arrived at. Comparing this figure with that representing the cranial volume a very slight error is observed in those cases in which the cerebral blood was allowed to escape into the thorax previous to the examination of the head. In the latter cases the discrepancy represents this loss and can be readily identi. fied by a study of the chart.

Having ascertained the above data, it was thought to be best for purpose of study to arrange the cases in groups corresponding to the amount of pial edema present.

On examining Table 2 , in reference to the specific gravities, the recognized tendency for brains to become lighter at the extremes of age is observed.

There is, however, a most important point which these tables have clearly brought out; i. e., that there is a gradually increasing discrepancy between the capacity of the brain cavity and the volume of the brain, which is directly proportional to the degree of pial edema present.

In Group 1, cases without pial edema, we see that the average discrepancy is only about 29 c.c., this figure being presumably the equivalent 


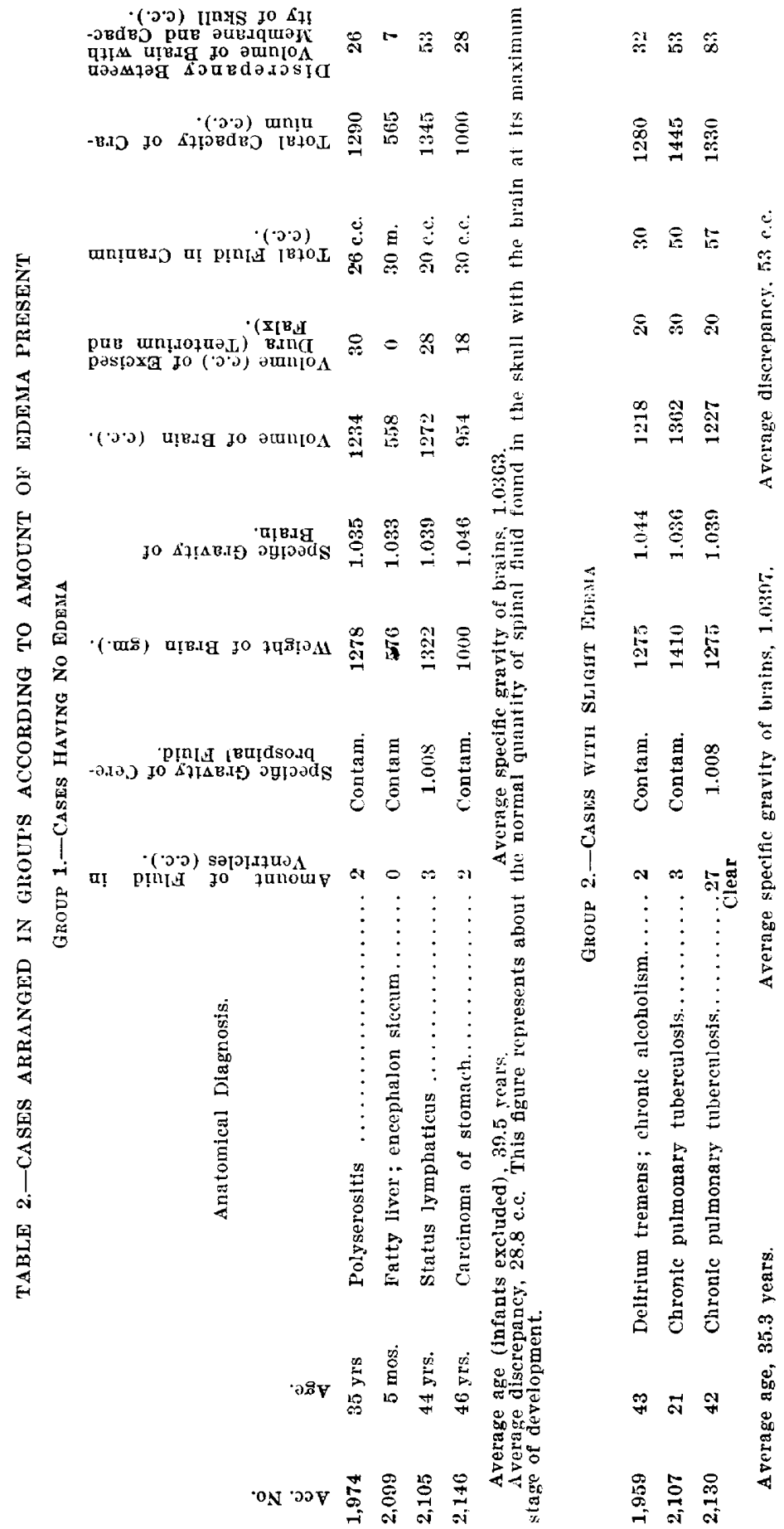




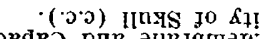

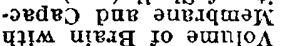

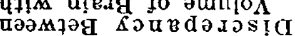

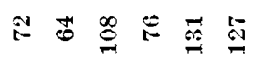

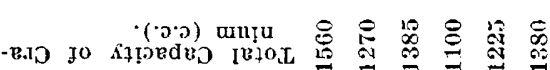

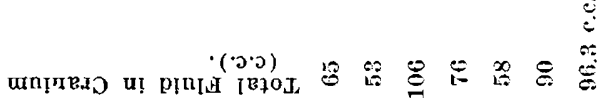

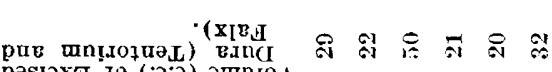

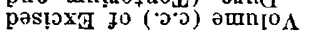

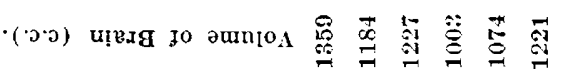

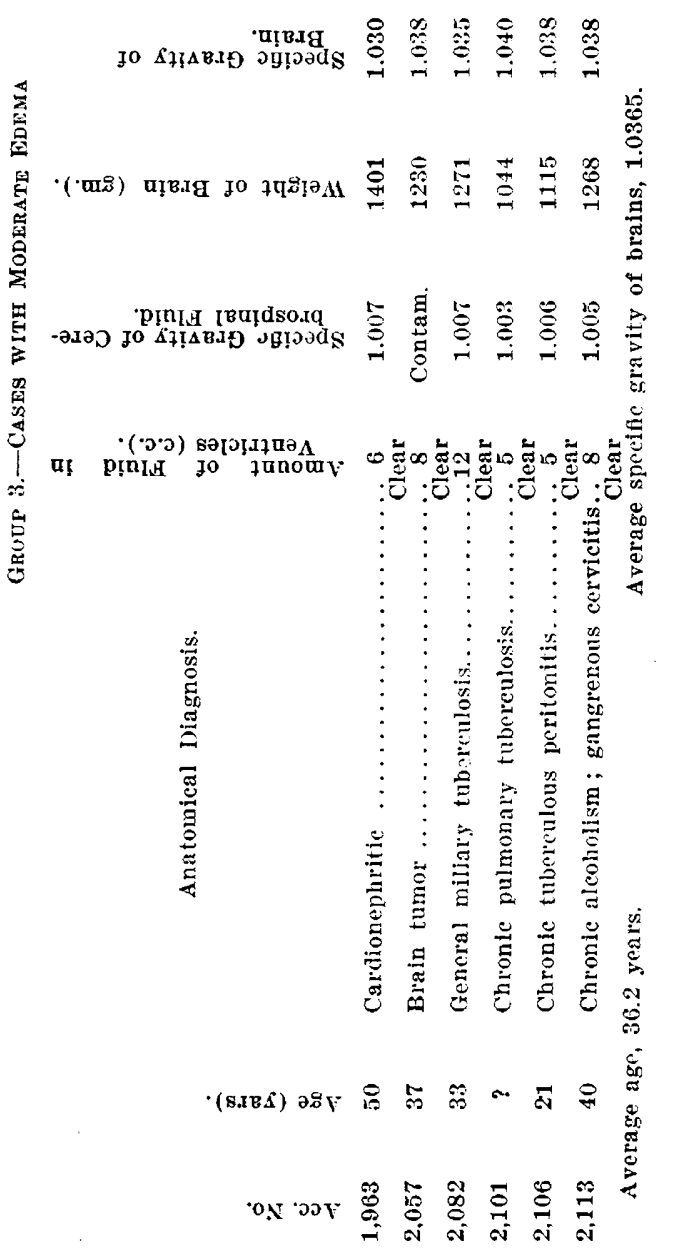

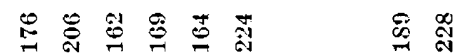

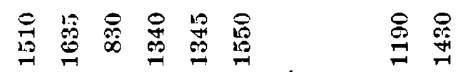

$=8$\begin{tabular}{ccc}
0 \\
\hdashline
\end{tabular}

$=$

ㅈำ

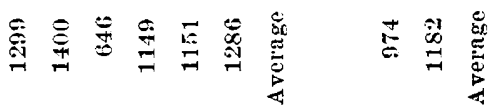

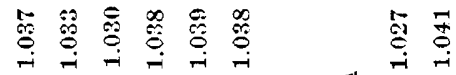

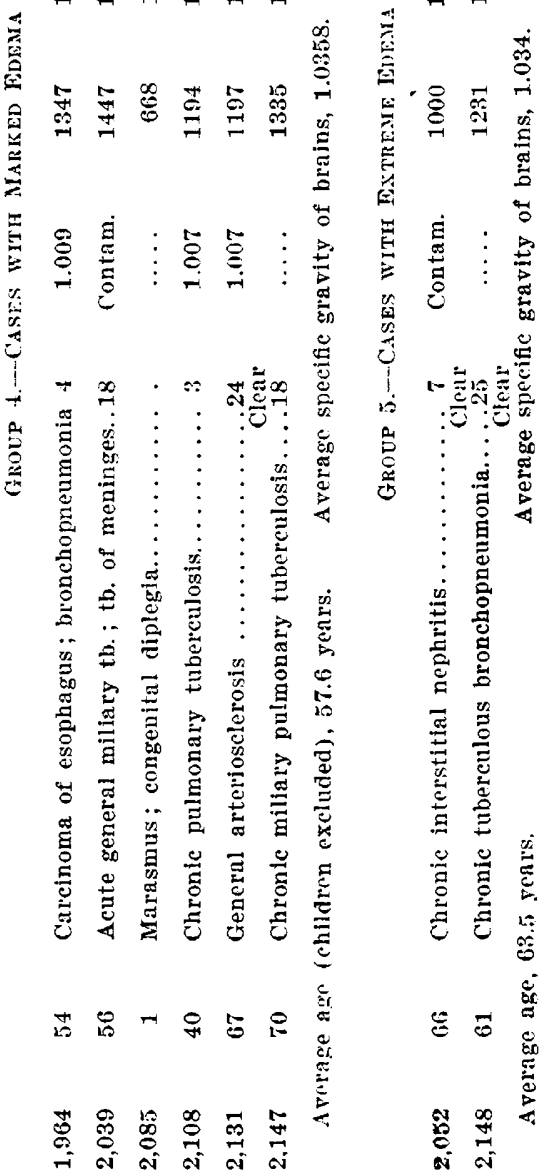


of the cerebrospinal fluid present. In these cases the brain may be assumed to fill the skull cavity within physiological limits.

In Group 2, where the edema is slight, there is an average total discrepancy of 53 c.c., an increase of 24 c.c. over the preceding class.

As the edema increases, there is a corresponding increase in the discrepancy. In the remaining groups it is, with moderate edema, 96 c.c.; with marked edema, 183 c.c.; and lastly, in the two cases of excessive edema in the series the discrepancy culminates with 208 c.c. as a maximum, this in spite of the fact that one of the cases examined had a very small skull. This discrepancy can, of course, be interpreted in only one way, i. e., that the brain has become so reduced in size as not to fill completely the cranial vault.

Trere compression the cause of this reduction in size there should be a corresponding increase in the specific gravity of these brains, proportional to the degree of edema. This, we see, is not present; indeed, if it is permissible to say anything at all in this connection, it is that the specific grarity has fallen slightly with the higher grades of edema. To say merely that the condition is a hydrops ex vacuo does not, by any means, dispose of the whole subject; let us therefore resume the consideration of the data before us.

Leaving out of account the two cases cited, in very young children. we observe that the more vigorous periods of life coincide with the milder degrees of discrepancy between brain and skull cavity, while the more marked differences are exhibited in the more advanced periods of life. It has been universally recognized that shrinkage of the brain is an accompaniment of extreme old age, but the extent to which this phenomenon reaches back into the years of vigorous manhood has not been generally considered.

Table 3 shows the brain weight at different ages; for children only, br Parrot, ${ }^{101}$ Pfister, ${ }^{102}$ and Marchand $;^{103}$ through childhood up to the twenty-fifth year by Vierordt; ${ }^{104}$ at all ages Boyd, ${ }^{105}$ Meynert ${ }^{106}$ and Handmann $;^{107}$ and from the twentieth to the ninety-fifth year, Bischoff. ${ }^{108}$

101. Parrot: Bull. Soc. d'Anthropol. de Paris, 1887. le Mars.

102. Pfister, H.: Ueber das Gewicht des Gehirns und einzelner Hirntheile beim Säugling und älteren Kinde. Neurol. Centralbl,, 1903, xxii, 562.

103. Marchand: Ueber das Hirngewicht des Menschen, Abhandl. d. math.phys. Classe d. kgl. Sächsischen Gesellsch. d. Wissensch., 1892, xxvii, 437.

104. Vierordt, H.: Anat. Physiol. u. Physikal. Daten und Tabellen, 1906, Jena. 105. Boyd: Phil. Tr. Roy. Soc. London, 1861, cli, 242.

106. Meynert, Th.: Das Gesammtgewicht und die Theilgewichte des Gehirnes in ihren Beziehungen zum Geschlechte, dem Lebensalter und dem irrsin, untersucht nach einer neuen Wägungsmethode an den Gehirnen der in der Wiener Irrenanstalt im Jahre 1866 Verstorbenen, Vrtljschr. f. Psychiat., 1867, ii, 125.

107. Handmann, Ernst: Ueber das Hirngewicht des Menschen, etc., Arch. f. Anat. u. Entwcklngsgesch., 1906, p. 1.

108. Von Bischoff, T. L. W.: Das Hirngewicht des Menschen (von P. Neusser) Bonn, 1880. 


\begin{tabular}{|c|c|c|c|c|c|c|c|c|c|c|c|}
\hline \multirow[b]{2}{*}{ Age } & $\begin{array}{l}\text { TABLE } \\
\text { [ERORDT }\end{array}$ & $-\mathrm{G}$ & \multicolumn{3}{|c|}{$\begin{array}{l}\text { BRAIN } \\
\text { PARROT }\end{array}$} & $S$ OF CI & $\begin{array}{l}\text { LDREN } \\
\text { FISTER }\end{array}$ & D & Ma & RCHAN & \\
\hline & \multicolumn{2}{|c|}{$\begin{array}{l}\text { Weight (gm.) } \\
\text { Males Females }\end{array}$} & Age & \multicolumn{2}{|c|}{$\begin{array}{l}\text { Weight (gm.) } \\
\text { Males Females }\end{array}$} & Age & \multicolumn{2}{|c|}{$\begin{array}{l}\text { Weight (gm.) } \\
\text { Males Females }\end{array}$} & Age & \multicolumn{2}{|c|}{$\begin{array}{l}\text { Weight (gm.) } \\
\text { Males Females }\end{array}$} \\
\hline n.. & & & & & & & $340^{*}$ & $330^{*}$ & & & 1 \\
\hline & & & & 364 & & & & & & & \\
\hline$\cdots$ & $\begin{array}{l}548 \\
0.632\end{array}$ & 52 & & $\begin{array}{l}490 \\
575\end{array}$ & $\begin{array}{l}412 \\
552\end{array}$ & $\begin{array}{l}\operatorname{mos} \ldots \\
\operatorname{mos} \ldots\end{array}$ & & & & 6 & \\
\hline & 733 & & -11 mos. & 778 & 719 & $4-5$ mos. & 58 & 562 & & & \\
\hline aos. & & & & $\cdots \cdot$ & $\ldots \ldots$ & 6-8 m & 7 & & $7-11 \mathrm{mos}$ & 796 & 81 \\
\hline ye & .944 & & 1-2 years. & $\ddot{9} \dot{6} \dot{4}$ & $\ddot{9} \dot{1} \dot{3}$ & 11-12 mos. & 85 & $\begin{array}{l}684 \\
727\end{array}$ & & 967 & $\ddot{8} \dot{9}$ \\
\hline & $.1,112$ & & & & & & 958 & 901 & $1-2$ & 1,0 & \\
\hline & & & $2-4$ years. & 1,167 & 1,063 & & 1,099 & 1,04 & & & 1,0 \\
\hline . & $.1,2$ & & 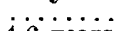 & 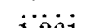 & & & 1,183 & 1,091 & & & \\
\hline & $.1,3$ & 1,2 & 4-6 years. & . 1,261 & 1,137 & & .... & $\ldots \ldots$ & & 1,2 & \\
\hline $\begin{array}{l}\text { ye } \\
\text { ye }\end{array}$ & & $\begin{array}{l}1,2 \\
1,1\end{array}$ & : & $\cdots \cdots$ & $\cdots \cdots$ & $5-8$ years. & 1,219 & $\ldots$ & ars. & 1, & $\begin{array}{l}1,245 \\
5 \\
\text { yr's. }\end{array}$ \\
\hline ye & & & & $\cdots \cdots$ & $\ldots$. & $\ldots \ldots$ & $\ldots$. & $\ldots \ldots$ & & & \\
\hline$y$ & $.1,4$ & & 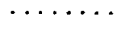 & $\cdots \cdots$ & $\cdots \cdot$ & 0.1 & 10 & 065 & $6-9$ years. & 1,360 & 1,242 \\
\hline & 1, & & & $\cdots \cdots$ & $\cdots \cdots$ & $9-12$ yrs. & $\begin{array}{l}1,285 \\
1,289\end{array}$ & $\begin{array}{c}1,265 \\
\ldots \ldots\end{array}$ & 10-14 yrs. & 1,346 & 1,221 \\
\hline yea & 1,4 & & & $\ldots$. & $\ldots$. & $\ldots$ & ..... & $\ldots .$. & ......... & 5 & \\
\hline & & & & & $\ldots$ & & ${ }^{2}$ & $\ldots \ldots$ & - & $\ldots$ & $\ldots \ldots$ \\
\hline & & & & $\ldots$. & $\ldots \ldots$ & . & $\ldots \ldots$ & $\ldots \ldots$ & . & $\cdots$ & $\ldots$ \\
\hline yeg & 1,4 & $\begin{array}{l}1,2 \\
1,2\end{array}$ & & $\ldots$ & $\cdots$ & & $\cdots$ & $\ldots$ & $15-19$ y s. & 1.404 & 1309 \\
\hline & & & & $\ldots$ & $\ldots$ & & $\ldots$. & $\cdots$ & $\ldots \ldots$ & $4, \ldots 07$ & $\begin{array}{l}1,000 \\
\ldots .\end{array}$ \\
\hline & & & & $\cdots$ & $\cdots$ & & $\ldots \ldots$ & $\cdots$ & & $\ldots$. & $\ldots \cdot$ \\
\hline ye & .1 & & & . & $\cdots$ & & $\cdots$ & $\because$ & & & \\
\hline & & & & $\ldots \ldots$ & $\ldots$ & 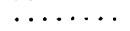 & $\ldots$ & $\ldots \ldots$ & & $\ldots$ & $\ldots$ \\
\hline & & & & & & & .... & $\cdots$ & & & \\
\hline & & & & & & & & & & & \\
\hline & & & & & & & & & & & \\
\hline
\end{tabular}

* Parrot's, Pfister's and Marchand's ages same as in Vierordt's column unless otherwise indicated.

\begin{tabular}{|c|c|c|c|c|c|c|c|c|c|c|c|}
\hline \multirow{3}{*}{$\begin{array}{c}\text { Age } \\
\text { 7 days.... } \\
8-30 \text { days }\end{array}$} & \multicolumn{2}{|c|}{ ANDMAXX } & \multicolumn{6}{|c|}{ Group 2.-Brain Weights at All Ages* } & \multicolumn{3}{|c|}{ BISCHOFF } \\
\hline & \multicolumn{2}{|c|}{$\begin{array}{l}\text { Weight (gm.) } \\
\text { Males Females }\end{array}$} & Age & \multicolumn{2}{|c|}{$\begin{array}{l}\text { Weight (gm.) } \\
\text { Males Females }\end{array}$} & Age & \multicolumn{2}{|c|}{$\begin{array}{l}\text { Weight (gm.) } \\
\text { Males Iemales }\end{array}$} & Age & \multicolumn{2}{|c|}{$\begin{array}{l}\text { Weight (gm.) } \\
\text { Males Females }\end{array}$} \\
\hline & $\begin{array}{l}239 \dagger \\
404 \ddagger \\
357\end{array}$ & $\begin{array}{l}2479 \\
3771 \\
357\end{array}$ & & $\begin{array}{l}\cdots \cdots \\
\ldots \ldots\end{array}$ & $\begin{array}{l}\cdots \cdots \\
\cdots \cdots\end{array}$ & $\begin{array}{l}\text { Newborn. } \\
\text { i-3 mos.. }\end{array}$ & $\begin{array}{r}393 \\
\cdots 4 \dot{3}\end{array}$ & $\begin{array}{r}347 \\
\cdots 495\end{array}$ & & $\begin{array}{l}\cdots \cdots \\
\cdots \cdots \\
\ldots \ldots\end{array}$ & $\begin{array}{l}\cdots \cdots \\
\cdots \cdots \\
\cdots \cdots\end{array}$ \\
\hline $\begin{array}{l}3 \text { mos. } \\
6 \text { mos.. }\end{array}$ & $\begin{array}{r}485 \\
650\end{array}$ & $\begin{array}{l}486 \\
490\end{array}$ & & & & $i-$ & $\begin{array}{l}603 \\
777\end{array}$ & $\begin{array}{l}\ddot{5} \dot{560} \\
709\end{array}$ & & $\ldots \ldots$ & $\cdots \cdots$ \\
\hline s. & $\begin{array}{r}830 \\
1.075\end{array}$ & $\begin{array}{l}8 . \\
9\end{array}$ & & $\cdots \cdots$ & $\cdots$ & 1-2 years. & & 84 & & $\cdots \cdots$ & $\cdots \cdots$ \\
\hline & 1,2 & & & & $\cdots$ & $2-4$ years. & $\ddot{1}, \dot{0} \dot{9}$ & $\dot{9} \dot{9}$ & & $\cdots$ & $\cdots$ \\
\hline & & 1,17 & 1-19 yrs. & 1,114 & $\ldots$ & & & 110 & & $\ldots \ldots$ & $\ldots \ldots$ \\
\hline & 1,2 & 1,2 & & & $\cdots \cdots$ & $4-6$ years. & 1,140 & $1,13 \bar{\tau}$ & & $\cdots$ & $\cdots \cdots$ \\
\hline & $\begin{array}{l}1,215 \\
1,345\end{array}$ & 1,283 & & & & $6-14$ yrs. & 1,304 & $\ddot{1}, \dot{1} \dot{1} 6$ & $\therefore$ & $\cdots \cdots$ & $\cdots \cdots$ \\
\hline & $\begin{array}{l}1,40 \\
1,42\end{array}$ & $\begin{array}{l}1,21 \\
1,28\end{array}$ & $\therefore$ & $\cdots$ & $\because$ & yis. & 1,376 & $1, \approx 46$ & $\because$ & $\cdots \cdots$ & $\cdots \cdots$ \\
\hline & & 1,2 & & & & 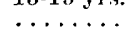 & & $2 x$ & & 1,396 & $\dddot{1}, 234$ \\
\hline & & 1,2 & & 1,3 & & & & & & & \\
\hline & & & & & & & & 1,2 & & 1,366 & 1,240 \\
\hline s. & & & & 1,3 & 1 & & 1,3 & 1,214 & & $\ldots \ldots$ & .... \\
\hline & & 1 & & $\ddot{1}, \dot{2}$ & 1 & & & & & 1,3 & 1,200 \\
\hline & & & & & & & & & & & \\
\hline & & & $\ddot{0}$ & 1,206 & & & & & & & \\
\hline & & & 80-89 yrs. & ..... & & O.. & & & $80-85 \mathrm{yrs}$ & 1,023 & 942 \\
\hline
\end{tabular}

* Meynert's age grouping follows Handmann's and Bischof's; is similar to Boyd's except when otherwise indicated.

$\leftarrow$ Boys under $49 \mathrm{~cm}$. length of body.

$\ddagger$ Boys over $50 \mathrm{~cm}$. length of body.

Girls under $50 \mathrm{~cm}$. length of body.

1) Girls from 50 to $55 \mathrm{~cm}$. length of body. 
The highest figures reached in Vierordt's column, Table $3(\mathbf{1 , 4 7 5} \mathrm{gm}$.) occur at the age of 13 years in males. Among the females the highest weight recorded is $(1,345 \mathrm{gm}$.) at the age of 14 . This table, however, can scarcely be considered complete enough for our purposes.

Boyd's figures give the period of maximum weight as between 15 and 19 years, with a subsequent loss up to the age of 80 of about $90 \mathrm{gm}$.

Bischoff represents an irregular decline from 20 to 30 onward in males. His highest figure quoted in females, however, is between 40 and 50 .

Handmann finds that the greatest brain weight occurs in males between the seventh and fifteenth years and that after the twenty-ninth year there is a gradual and steady decline. In females, curiously enough, his highest recorded brain weight $(1,283 \mathrm{gm}$.) occurs in rather young children, seventh to ninth years. There is a slightly lower figure given for the period between the fifteenth and seventeenth years. There is, however, no rapid decline evident until middle age.

Peacock gives the maximum weight as between 25 and 30, Broca $^{109}$ at between 30 and 35, while Meynert's figures indicate that loss of weight begins even later in life.

Blakeman ${ }^{110}$ concluded that the human prime in brain weight seems to fall before the twentieth year and that after this period there is on the whole a continuous fall. Taken altogether these data afford clear evidence that recessive changes within the brain begin often quite early in life, although it is evident from the study of even such limited data as I present that in some cases the brain maintains its maximum volume until its possessor is well advanced in years.

From these data there may be noted a strong tendency on the part of the age curve of pial edema as plotted out from my series of 375 cases to coincide with a curve plotted out in accordance with a scale of loss of brain weight for equivalent ages, that is to say, as the curve for pial edema rises, the average of brain weights will be found to fall correspondingly from point to point on the chart.

Apart from the sudden rise in the pial edema curve between 30 and 40 years, due to the inclusion of the large number of alcoholics dying within this period, the evidence is strong that pial edema coincides with the reduction of brain weight that is common after puberty, and, such being the case, I infer that it is secondary to a reduction in size of the brain and that it therefore represents a replacement process due to the brain shrinkage.

109. Quoted from Quain's Anatomy, iii, Part 1, p. 178.

110. Blakeman, J.: A Study of the Biometric Constants of English Brain Weights and Their Relationships to External Physical Measurements, Biometrika, 1905, iv, 124. 
Such a shrinkage is of course to be looked on as entirely physiological. The discrepancy between the skull and the brain is doubtless to a sertain extent modified by the sensible shrinkage of the head diameters described by Blakeman ${ }^{111}$ as occurring in general hospital cases, but this is really slight, being very roughly only about $5 \mathrm{~mm}$. between the twentieth year and old age.

Pathological shrinkage of the brain, that due to contraction caused by disease, has long been recognized. Clapham ${ }^{112}$ in 1873 , CrichtonBrowne, ${ }^{113} 1879$, and Mercier ${ }^{114}$ in 1891 published observations on the subject of lessened brain weights in the insane drawn from large series of cases. Boyd's figures, with which Crichton-Browne agrees, are so tabulated as to be readily intelligible; they are given in Table 4.

Donaldson in considering this table ${ }^{115}$ regards the last three on the list as those in which wasting of the brain takes place.

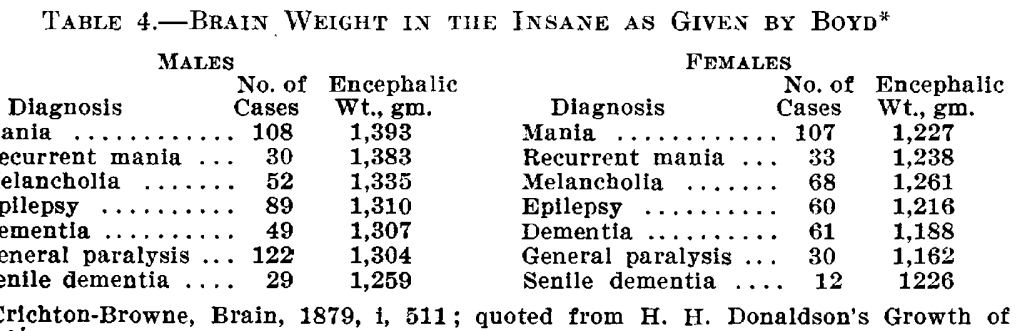
the Brain.

Kaufmann ${ }^{118}$ describes general cerebral atrophy in connection with old age, prolonged illness, chronic lead poisoning, alcoholism and dementia paralytica. Our researches in connection with pial edema confirm the statements in regard to old age and alcoholism and indirectly disagree with that in regard to prolonged illness, ${ }^{117}$ but do not cover the other conditions mentioned.

A]together I may summarize by saying that pial edema follows atrophy of the brain; first, in the great majority of instances as a result of

111. Blakeman, J.: Biometrika, 1905, iv, 138. He found no shrinkage in the head diameters of criminals, but states that the subject has not been fully worked out for the general population.

112. Clapham, C.: The Weight of the Brain in the Insane, West Riding Asyl. Med. Rep., iii, vi.

113. Crichton-Browne, J.: The Weight of the Brain and Its Component Parts in the Insane, Brain, 1879, i, 504; ii, 42.

114. Mercier, C. A.: The Weight of the Brain in the Insane with Reference to Hemispheres, Lobes, Brain-Stem and Cerebellum, Jour. Ment. Sc., 1891, xxxvii, 207.

115. Donaldson, H. H.: Growth of the Brain, 1895, pp. 137-140.

116. Kaufmann, E.: Spezielle Pathologische Anatomie, Ed. 5, Berlin, 1909, p. 1094.

117. My figures already given under "Nutrition" in Part 1 have shown an absence of relationship between pial edema and wasting of the rest of the body. 
physiological changes beginning at or soon after puberty; second, in a smaller group as the result of certain pathological conditions, notable among which are chronic alcoholism ${ }^{118}$ and certain forms of insanity.

My earlier review and demonstration of the principles underlying intracranial pressure is justified, first, by the necessity of ruling out a hypothetical cause (namely, local compression) for the appearances noted in cases of well-marked subarachnoidal edema; secondly, by the evident need of restating these principles to those observers on serous meningitis who have apparently overlooked them, and, lastly, by the necessity of reviewing the fundamentals before entering into such discussion of the more complex and minute phases of the question as is inevitable in a consideration of the relations that exist between the present work and the conceptions of the Traube school, the observations of Kolisko and the experimental work of Mott and of Cannon.

In connection with Mott's work, his findings of increased fluid in the skulls of general paralytics ${ }^{119}$ are in accord with the well-recognized tendency of these eases to brain shrinkage and consequent hydrops ex racuo. as already pointed out. It must not be forgotten that brain shrinkage nsually implies a widening of the perivascular spaces similar to that seen in senile brains and graphically described by Gowers. ${ }^{120}$ Such a condition is frequently encountered at autopsy, and it is not strange that the excessive moisture found on section of the brain should often be erroneonsly ascribed to a dilatation of those spaces by serum transuded from the blood-ressels. As a matter of fact it seems to be questionable whether dilatation of these "lymphatic" spaces is a possibility. Mott adheres to the view, based on microscopical observations, "that the whole brain is permeated by a canalicular Iymph-system containing cerebrospinal fluid, the large processes of the neurons lying in lymph-spaces which are continuous with the perivascular lymphatics."121

If these observations are true, then dilatation of the perivascular canals by transudate from contained blood-vessels is impossible, since pressure exerted within them would be readily transmitted by the serum to the surrounding tissue and wonld therefore be everywhere equal and thus prevent such a phenomenon.

As a matter of fact there is some evidence to show that the perineuronal lymph-spaces are not so readily permeable as is generally believed I have met striking lack of success in attempting to perfuse methyleneblue normal saline solution into fresh brains under varying degrees of

\footnotetext{
118. The shrinkage in the brains of chronic alcoholics may be explained by the noteworthy changes in the ganglion cells of such cases as taught and demonstrated by Dr. Ira Van Gieson many years ago.

119. Quoted by A. E. Russell, p. 1095 .

120. Gowers, William R.: Abstract of a Lecture on The Nervous System in Old Age, Polyclinic, London, 1907, xi, 131.

121. Mott: Areh. Neurol., London, i, 499.
} 
pressure. Whether the apparent impermeability of the brain represents a true finding or whether this failure to demonstrate ready permeability was due to faulty technic or unconsidered factors of capillarity cannot be stated the technic ${ }^{122}$ was similar to that successfully employed by Brodie in demonstrating the permeability of other organs.

I shall not consider Mott's production of edema of the brain in animals by experimental ligation of arteries, ${ }^{121}$ since his description shows plainly that his conception of brain edema is widely divergent from that held by the Traube school.

His reference to the ease with which the perineuronal spaces were made out in some of the cases of experimental anemia ${ }^{121}$ is of lessened significance when I remind the reader that these appearances are often due to artifacts. Also it must not be overlooked that Huguenin ${ }^{123}$ has observed from experiments on animals that a given brain is moister after death than during life.

The essential point to be held in mind in connection with the transudate theory is that pressure continuity exists throughout all the fliid molecules in the cranium. Pressure caused by transudation from the blood-vessels would be transmitted from molecule to molecule everywhere throughout the cranial cavity and spinal canal-it would be felt, generally speaking, as fully or nearly as much in the subarachnoid fluid on the outside of the brain as in that within the perivascular and interstitial spaces. Under these circumstances there would be no disarrangement of the brain, that is to say, no crowding up of the external portions against the bony vault. Nor could there be, as already stated, any measurable molecular compression although intracranial pressure were raised to great heights. Vascular compression would occur, but this would not explain the soggy condition of the tissues (often considerable from the gross and the histological point of view) intervening between the vascular spaces.

On physical grounds therefore we are not justified in maintaining. that transudation is a cause of cerebral edema, whatever rôle it may play in the production of edemas elsewhere. ${ }^{124}$

122. Personal Communication.

123. Huguenin: Handbuch der speziellen Pathologie und Therapie ron $v$ : Ziemssen, Suppl. Vol., 1878, p. 6.

124. The following descriptions taken from autopsy report No. 2,402, are interesting since they show that transudation does not necessarily take place within the skull as a result of thrombosis of the veins of the neck.

"Head: The longitudinal sinus is free; there is marked pial edema and a moderate amount of fluid at the base. The cerebral vessels are everywhere thin and normal. The pial veins over both superior convexities are normal with the exception to be noted below. The temporosphenoidal and occipital veins on the surface of the right side are the seat of firm, blackish coagula. On removing the brain, a large vein with its branches filled with blackish clot is found torn and lying on the superior surface of the petrous portion of the temporal bone. This 
The old idea propounded by Traube that cerebral edema is due to transudate has persisted with some tenacity in spite of the evidence to the contrary offered by Cannon (1901). With the exception of Cushing (1903 and 1908) ${ }^{\mathbf{2 4},{ }^{25}}$ it appears that the significance of Cannon's work has been largely overlooked.

Leyden, ${ }^{125}$ Duret, ${ }^{126}$ Cybulski ${ }^{125}$ and Hill ${ }^{128}$ all believed that intracranial tension must equal blood tension in order to produce death. Cannon, ${ }^{129}$ reasoning from their experiments, in an attempt to explain the mode of death after trauma of the brain; decides that transudation could not raise pressure sufficiently to bring this about, since pressure outside the vessels would not equal that within, owing to loss through resistance of the tissue.

The reader deduces for himself that since the accepted mode of death in cerebral edema is through high tension inducing arterial collapse, the cause of the cerebral edema cannot be transudation.

Cannon develops a theory of edema which differs radically from that of all other observers and in which he ascribes the swelling to osmosis induced by chemical changes in the brain-cells themselves. He finds a satisfactory analogy in the experimental work of Budgett ${ }^{130}$ and of Loeb $^{131}$ on muscle tissue, and supports his arguments by observations on the capacity of brain tissue when deprived of its blood supply to take up water from a solution isotonic with the blood. ${ }^{132}$

He lays no particular emphasis on causation but points out that Loeb and Budgett emphasized lack of oxygen as a probable cause of the chemical changes in their experiment, and demonstrates the manner in which

vein evidently formed a communication between the above-named veins and the lateral sinus. The lateral sinus and the bulb on the right side is the seat of a dark coagulum which is markedly adherent to the wall of the vein. The right middle ear contains an excessive amount of clear fluid. The right mastoid cells appear to be mostly closed, the bone being extremely firm and discolored yellowish. The left middle ear and mastoid normal. Cross-section of the brain reveals no gross lesions. There is no edema of the brain substance. The lateral ventricles were not distended and contained a normal amount of fluid.

"Blood-Vessels: The inferior vena cava is normal. The superior vena cava, the right innominate, right and left internal jugular and left external jugular veins are markedly thickened and the seat of an old firmly adherent and partially organized thrombus, which is paler at its cardiac end than toward the head."

125. Leyden, E.: Beiträge und Untersuchungen zur Physiologie und Pathologie des Gehirns, Arch. f. Path. Anat., 1866, xxxvii, 519.

126. Duret, H.: Etude expérimentales et cliniques sur les traumatismes cérébraux, Paris, 1878, p. 183.

127. Cybulski, N.: Zur Frage des Gehirndruckes, Centralbl. f. Physiol., 1891, iv, 834 .

128. Hill, L.: The Physiology and Pathology of Cerebral Circulation, p. 168.

129. Cannon: Am. Jour. Physiol., 1901, vi, 101, 102.

130. Budgett, S. P.: The Similarity of Structural Changes Produced by Lack of Oxygen and Certain Poisons, Am. Jour. Physiol., 1898, i, 210.

131. Loeb: Arch. f. d. ges. Physiol,, 1898, lxxi, 47.

132. Cannon: Am. Jour. Physiol., 1901, vi, 114, 115. 
lack of oxygen would follow as a result of circulatory changes resulting from brain contusion.

Cannon's idea that lack of oxygen sets in motion the processes described, while satisfactory from a surgical standpoint, does not seem to apply equally well to other pathological conditions.

His theory has the merit that it is the only one so far given that is unassailable from the standpoint of mechanics and I cannot but feel that the process described, or something like it, is responsible for all true cases of cerebral edema, meaning by this edema of the brain as distinguished from pial edema.

Cannon ${ }^{133}$ suggests a seeming objection to the working out of his theory in the occurrence of fluid noted in the dura or in the ventricles in certain recorded cases; "for why," he says, "does not the fluid pass into the tissues rather than accumulate if the tissues have the great osmotic power attributed to them?" He believes that the question cannot be definitely settled until the osmotic pressure of the fluids has been determined; he adds that the fluids must be encapsulated, and gives the following as a possible explanation:

The diffusion of salts from the injured tissues into even a slight amount of fluid in an encapsulated space would render that fluid of higher osmotic pressure than the blood-plasma. The plasma would thereupon pass into the encapsulated space in obedience to osmotic laws and thus increase the fluid in its compressing effect. Further change in the injured tissues would lead to greater swelling in them and to diffusion of more of the dissolved products of decomposition. The diffusion into the encapsulated fluid would still further increase its osmotic pressure, and result in still more plasma coming to inerease its volume. Thus there would be a passage of salts from tissues to blood in a series of decreasing concentrations, and a passage of fluids to tissues in a series of increasing osmotic pressures. And since water will pass more rapidly than salts through membranes, the result is usually a greater and greater pressure until death supervenes.

The importance of emphasizing Cannon's frank objection to his own theory and his explanation of the same is that if unanswered it affects our own theories and conclusions as well. Such a subdural process as that to which he refers suggests in a way as an analogy, a subdural hydrocephalus-a process in regard to which we know extremely little. Fluid in any amount is so seldom seen post mortem $^{134}$ in the subdural space

133. Cannon: Am. Jour. Physiol., 1901, vi, 119.

134. Huguenin has discussed this matter rather carefully. It seems curious that some writers have failed to realize that the cranial subdural space is distinct from the subarachnoid space and its spinal prolongation, for, owing to the close apposition of the membranes, at the foramen magnum, there is no subdural space in the spinal canal. To illustrate my meaning, bloody spinal fluid has been considered to be an evidence of middle meningeal hemorrhage, whereas the presence of blood in this fluid in such cases is only an indication of rupture of the dura and subarachnoid membrane or cerebral laceration. In suppurative internal pachymeningitis the cerebrospinal fluid is clear unless there has been an extension of the process to the pia. 
that we seldom expect to come across anything except the yellowish serous fluid that often accompanies a pachymeningitis hemorrhagica interna. Possibly this fluid may not be so readily absorbed as the normal spinal fluid of the subarachnoid space.

More frequently during life the subdural space seems to contain thin exudate of an apparent inflammatory origin, especially where there is middle ear disease. This exudate, or transudate, may or may not represent the incipient stage of a purulent pachymeningitis and has more than once been described by operating otologists as meningitis serosa. Considering these facts, it seems unwise to attempt to draw any conclusions as to why subdural fluid seems to remain in the subdural space in some cases of apparent brain edema when one might naturally expect that it would be squeezed out.

Cannon's explanation as to the action resulting from the diffusion of salts from injured tissues into an encapsulated space, while theoretically sound for dead membranes, ignores the fact that living animal membranes have a selective action permitting the passage of one ion or molecule and preventing the passage of others, and he also appears to overlook the fact that such diffusion would affect primarily the subarachnoid fluid which directly envelops the brain tissue. We actually do not know the mode of absorption of the subarachnoid fluid nor what relation it bears to the subdural fluid, for experiments thus far conducted have not settled this point. Furthermore. were the resorption of the subarachnoid fluid interfered with, the type of swollen brain described by Traube and Kolisko could not occur since its change in volume must necessarily be largely at the expense of spinal fluid.

In regard to the occurrence of accumulations of fluid in the ventricles, of which Cannon speaks, ${ }^{133}$ several hypotheses may be offered; first, that the cases mentioned were not those of actually swollen or edematous brains; second, that if they were the edema was in its incipience; third, that there was some obstruction to the outflow of spinal fluid from the ventricles. It is conceivable that under certain conditions of acute brain swelling such a result might be brought about. The oft-described permeability of the brain does not always seem to hold good, for cases have occurred in our experience with apparent sudden onset in which flattened dry convolutions, dry cut section and distended rentricles afforded almost proof positive of a confined and increasing ventricular secretion.

A newer theory of edema than that offered by Cannon and one which applies equally well to intracranial conditions is that recently advanced by Fischer. ${ }^{13 \pi}$ This theory, built on experiments, assumes that certain alterations in the fluids of the body, as for example too great alkalinity

135. Fischer, Martin H.: The Nature and the Cause of Edema, Tre Jocrsal A. M. A., 1908, li, 830 . 
or acidity (including excess of carbon dioxid) so increases the affinity of colloids for water that they become swollen with resultant edema and swelling of the tissues. Fischer cites as examples of this action of colloids, swellings due to stings of insects, the swelling of gangrenous tissues when water is applied to them, and the swelling of dead bodies kept in water, as cases in point. The brain is rich in colloidal substances which, should they suddenly begin to absorb water, ${ }^{136}$ would increase its volume in such a manner as to force all the cerebrospinal fluid from the skull. A subsequent evacuation of a certain amount of fluid into the tissue spaces of the brain, according to the mechanism described by this writer, would give rise to the soggy appearance observed.

While the type of brain of which I have been speaking is undoubtedly the one which 'Traube's followers have had in mind in their discussions, it is evident that they have now and then (through oversight of a mechanical principle) confused the swollen edematous brain with the more common form in which there is extensive or moderate pial edema and more or less moisture of the brain substance-the type which has been demonstrated as a physiological or pathological brain shrinkage.

In the first place, although it is impossible for the brain and subarachnoidal fluid to be increased at the same time, ${ }^{137}$ certain of the cases are so described as to imply that this may have taken place. In Cushing's article $e^{138}$ in connection with subtemporal decompression in a case of chronic nephritis which has already been referred to, we are told that there was considerable fluid in the subarachnoid space and that the arachnoid membrane was pricked to allow of this escaping. The obvious deduction on reading Cushing's article is that he was dealing with the

136. This theory of colloidal absorption is not generally regarded as proved. It is well known, however, that myelin substances are capable of absorbing large quantities of water.

137. Unless we allow the brains in question to have been markedly shrunken beforehand and admit that they have become swollen since. In such cases we can at least be sure that the edema itself could have played no part in the production of pressure symptoms.

138. On page 488 Cushing describes the operation at this stage as follows: "The dura was exceedingly tense and owing to the marked degree of cerebral protrusion that followed the first incision, it was opened with considerable hesitation in the absence of coincident lumbar punctures. It was accomplished, however, without injury to the pia arachnoid. The subdural space contained no free fluid. The arachnoid on the other hand was markedly distended with fuid which escaped after pricking the membrane in a number of non-vascular spaces where it bridged the exposed sulci. Not only was there a superabundance of fluid in the arachnoid space but the brain itself appeared soggy and wet." This picture it seems is hardly compatible with our conception of the swollen edematous brains described by Traube unless we accept the paradox that in this instance both brain volume and subarachnoid fluid contents were simultaneously increased. The mechanical complications arising as the result of a subsequent cerebral hemorrhage in the right hemisphere (see page 494 autopsy report of same article) certainly renders the case of little value from the standpoint of the study of cerebral edema. 
type of brain which has been especially discussed in this paper, and not with a true case of edema of the brain, as he may have supposed.

Similarly Phelps ${ }^{139}$ cites a case of a patient dying of traumatic brain injury (the age is not given) in which there was moderate subarachnoid effusion and well-marked edema of the brain. Cannon ${ }^{140}$ cites this case as an example of brain edema. To multiply such instances is unnecessary.

The conclusion to which we are led, based on the fact that in over 1,000 antopsies taken from the records of the Bellevue Laboratory, ${ }^{141}$ there have occurred no truly swollen or edematous brains of the types described either by Kolisko or by Traube, is that these brains are so rare that they cannot figure to any great extent in the common run of those diseases or surgical conditions which they are popularly supposed to accompany and that in many instances the inferences drawn at the autopsy table are incorrect ones based on an improper interpretation of the ordinary appearances of pia arachnoidal collections of fluid, especially where there is also present some widening of the perivascular spaces. It must be remembered, in referring to Kolisko's cases, that the number of autopsies which he has performed is enormous.

Another type occasionally seen is that in which there is general apparent increase in the volume of the brain, diminution in the size of the ventricles, decreased or absent subarachnoid fluid and pronounced flattening of the convolutions; but in none of these cases has there been any increased moisture from the cut surfaces of the hemispheres. On the contrary they have exhibited a rather more than normally dry or glazed appearance. ${ }^{142}$

The relations existing between pial effusions and the appearances described as serous meningitis are such as to create confusion. This is chiefly because the common milky patches on the arachnoid are apt to be mistaken for active inflammatory processes, while any free fluid made out in the subarachnoid space is consequently assumed to be serous unless it is slightly cloudy. ${ }^{143}$

A critical review of the literature of serous meningitis leads one to the conclusion that a great deal has been written on the subject which will not bear analysis; indeed, such an examination causes one to question whether, taking into account the various possibilities of mistake, the

139. Phelps: Traumatic Injuries of the Brain and Its Membranes, vi, 536.

140. Cannon: Am. Jour. Physiol., 1901, vi, 97.

141. Dr. Norris tells me he has never observed this condition, although he has for four years been on the watch for it.

142. A case of this sort is included in our tables of cranial weights and volumes, note Group II, Accession No. 2,099, Table 5.

143. In such cases a careful bacteriological examination must be made to eliminate a beginning inflammatory process, especially in pneumonia. 
disease can be said to have been positively demonstrated. Thiemich ${ }^{144}$ observes that "the term serous meningitis is primarily anatomical and as such is ambiguous," a statement the truth of which becomes increasingly apparent with added study. The instability of the foundations on which the study of the subject of serous meningitis has been made to rest is made apparent when one analyzes the fourteen cases on which Quincke $^{145}$ based his clinical observations. The first six cases were entirely clinical lasting up to five months with acute onset, acute course and recovery. No bacteriological work was done. A second group described as "acute cases with a chronic course," comprises three cases. Two of these came to autopsy and showed chronic internal hydrocephalus with tuberculosis elsewhere in the body.

In a third group comprising five cases and described as "chronic," three came to autopsy. The first of these showed a granular ependymitis with hydrocephalus internus and no tubercles. The second showed chronic hydrocephalus, ventricles very wide and filled with clear fluid, a granular ependyma, meningitis, extensive milky clouding of the pia, and slight opacity of the membranes of the cord. There was a large abscess in the pelvis, pyemic abscesses in the lungs, an old endometritis, and "myelitis (?)." No bacteriological examination was made. In a third case enormous hydrocephalus ( 800 c.c. of fluid) was present. For the entire group no histological findings are recorded, no bacteriological work was done, and intracranial pressure was measured only five times. Every case of Quincke's, therefore, which came to autopsy, was a case of internal hydrocephalus. It is hard to see on what grounds he based his assumption that in these cases the causative factor was a serous inflammation of the meninges. At the same time Quincke"146 informs us that "he did not find that the fluid in chronic serous meningitis differed from ordinary cerebrospinal fluid. Believing as $I$ do that the spinal fluid is a ventricular secretion, ${ }^{147}$ I cannot see how his point is demonstrated or how he differentiates his cases from the ordinary form of internal hydrocephalus.

Thiemich, as already noted, looks on the so-called acute hydrocephalus of childhood as a ventricular serous meningitis. He considers that the fluid of "internal" serous meningitis is usually clear but that there are slight changes which indicate inflammation of the chorioid plexus and ependyma.148 Possibly the terms "chorioiditis" and "ependymitis" are more suitable here.

144. Thiemich, Serous Meningitis in Diseases of Children, p. 413.

145. Quincke: Samml. klin. Vortr., pp. 656-668.

146. Quincke: Samml. klin. Vortr., p. 678.

147. The reader is referred to Brodie's Harvey Lecture, New York, 1909, on Renal Activity (the chorioid plexus being supposed to functionate as do the glomeruli).

148. For composition of the fluid in hydrocephalus, see under spinal fluid, Text-Book of Physiological Chemistry, Hammarsten Ed., 1908, p. 264. 
Quincke makes a statement in his article that has a distinct mechanical significance; he says: "In general venous stasis (as in valvular heart disease) we see, in addition to edema of the brain substance, increase in fluid not only in the ventricles but also, and usually in a higher degree, in the subarachnoid space, whereas local venous stasis leads only to transudation into the ventricles with transudation into the brain and compression of the convolutions against the skull."

Edema of the brain substance with increase in the ventricular and subarachnoid fluids is obviously a mechanical impossibility as already pointed out. The second statement implies a closure of the iter or foramina of Magendie.

Boenninghaus' series is equally as unsatisfactory as Quincke's. It is observed that most of his cases can readily be accounted for as either the beginnings of acute purulent or epidemic cerebrospinal meningitis, or as the chronic and partly healed phases of the same conditions.

It is hard to see how the condition can be demonstrated by the histological findings when we consider that the only way one can really prove that a given case of meningitis is serous in character and not some form of leptomeningitis with brain shrinkage, is by the presence of serous exudate.

Thiemich lays great emphasis on the bacterial, microscopical, and chemical examination of the spinal fluid in these cases and it seems safe to say that this is the only satisfactory method in making a diagnosis.

\section{PART 4.-THE CLINICAL SIGNIFICANCE OF PIAL EDEMA}

There are one or two points of importance that require consideration before closing. Of these the first to be considered is the question of the extent to which high intracranial pressure accompanies pial edema.

The simplest method of estimating intracranial pressure post mortem, as has already been stated, is by observation of the tenseness and bulging of the dura just after the skull is opened. Although only a rough guide, this method may be regarded as accurate enough for present purposes. In twenty-eight consecutive cases of pial edema examined, the dura was found tense in ten, indicating that high intracranial pressure coexisted with pial edema in more than one-third of the cases. Proof that the two conditions do not necessarily coexist is furnished by a case of pial edema which was tapped several hours before death by Dr. H. V. Guile, former intern of the Bellevue Hospital staff. The intracranial tension, as measured by him, was normal $\left(150 \mathrm{~mm}\right.$. of $\left.\mathrm{H}_{2} \mathrm{O}\right) .{ }^{149}$ Certain writers on alcoholism, including some recent ones, have looked on the presence of pial

149. See Accession No. 2,057, in Table 5 . 
edema as evidence of high intracranial tension; it seems wise in this connection to point out that in many cases symptoms which may have been due to coexistent high intracranial pressure were wrongly ascribed to a "wet-brain" found post mortem.

The second question worthy of attention is, May pial edema be looked on as a cause of symptoms? I have been at some pains to question the various house physicians as to the ante-mortem condition of the cases on which I performed the head autopsies, particularly those cases in which much edema was present. In Table 5 are the results obtained by this system of inquiry.

I give here a report of all cases as they occurred regardless of whether or not edema was present, but regrouped for convenience of study.

\section{Table 5.-Report of all Cases as they Occurred}

\begin{tabular}{|c|c|c|c|}
\hline \multicolumn{4}{|c|}{ Group 1} \\
\hline Acc. No. & Edema & Disease & Mental Condition Just Before Death \\
\hline 2,039 & $\mathbf{x x x}$ & Tuberculous meningitis. & Stupor present. \\
\hline 2,057 & $\mathbf{x x}$ & Brain tumor. . . . . . & $\begin{array}{l}\text { Stupor present ; (intracranial tension ante- } \\
\text { mortem was } 150 \mathrm{~mm} \text {. of } \mathrm{H}_{2} \mathrm{O} \text { ). }\end{array}$ \\
\hline 2,085 & $\mathbf{X X X}$ & Congenital diplegia $\ldots$ & Torpid from birth. \\
\hline 2,111 & $\mathbf{x x}$ & Uremia $\ldots \ldots \ldots \ldots$ & Uremic coma. \\
\hline 2,152 & $\mathbf{x}$ & Tuberculous meningitis. & Stupor present. \\
\hline
\end{tabular}

In this group are placed those cases in which the nature of the lesion is such that it would be difficult to determine the relation of stupor to the coexisting edema. Case 2,05\%, mentioned above, is of particular interest as suggesting that stupor with brain tumor is not necessarily dependent on high intracranial tension, as the tension in this case is normal.

Grovp 2.-No Pial Edema Present

\begin{tabular}{|c|c|c|c|}
\hline c. No. & $\begin{array}{l}\text { Degree of } \\
\text { Edema }\end{array}$ & Disease & Mental Condition Just Before Deatb \\
\hline 1,907 & $\ldots \ldots$ & $\begin{array}{l}\text { Chronic pulmonary tu- } \\
\text { berculosis. }\end{array}$ & No cerebral symptoms. \\
\hline 1,959 & & Delirium tremens ..... & Delirious till deat \\
\hline 1,974 & $\cdot$ & Polyserositis . . . . . . & No cerebral symptoms. \\
\hline 2,099 & $\ldots \ldots$ & $\begin{array}{l}\text { Fatty liver; cause of } \\
\text { death unknown; in- } \\
\text { fant. }\end{array}$ & Convulsions. \\
\hline, 109 & & $\begin{array}{l}\text { Pulmonary tuberculosis. } \\
\text { Carcinoma of stomach. }\end{array}$ & $\begin{array}{l}\text { No pressure or other cer } \\
\text { No cerebral symptoms. }\end{array}$ \\
\hline
\end{tabular}

The cases in this group have been included merely for the sake of completeness.

Of the following eighteen patients, nine had absolutely no symptoms of cerebral disturbance. Five were irritable or delirious, and four stuporous or comatose. Of the four cases last mentioned, two presented the picture known as "alcoholic wet-brain," a third was profoundly stuporous and a fourth comatose. Although included in this group, it is obvious 
that coma in a case of perforated gastric ulcer with fatal hemorrhage (Acc. No. 2,133) might readily be due to other factors than those caused by pressure of fluid on the cortex.

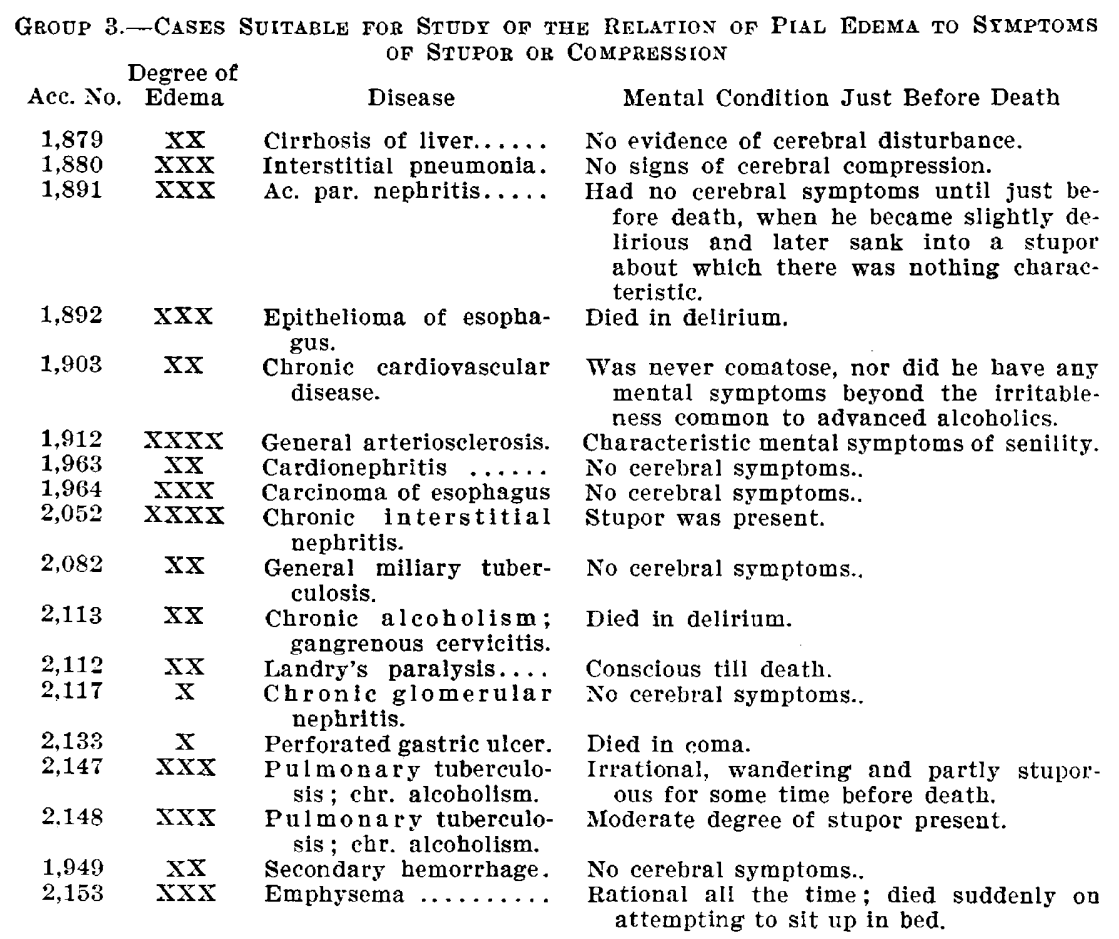

On review, there appears in these findings no evidence in support of the idea that pial edema is in itself a producer of symptoms. The symptoms of delirium tremens and "alcoholic wet-brain," it should be remembered in this connection, have been ascribed more properly by others to toxemia. My observations thus have led me to believe that such symptoms as have been recorded are the result of high intracranial pressure or toxemia $\left(\mathrm{CO}_{2}\right.$ or other poisons), or both, coexisting with pial edema, but not otherwise related to it.

\section{CONCLUSION}

My conclusions may be summed up as follows:

1. The collection of fluid in the pia mater is not per se a pathological process but in every instance represents the reciprocal of brain shrinkage.

2. It produces per se no symptoms.

3. Thickenings of the meninges in such cases take place chiefly in the arachnoid and are not to be regarded as representing a true inflammatory process. 
4. The brain increases in size up to puberty and diminishes thereafter proportionately to its diminution in weight, as shown by comparison with the tables of brain weights presented.

5. Increase or diminution in size of the brain is not determined by the state of nutrition of the rest of the body.

6. The appearance of "wet-brain" so called, or pial edema of alcoholics, is due to brain shrinkage and has no pathological significance per se.

7. The appearances of pia-arachnoidal effusion are readily mistaken for those of serous meningitis.

8. When a collection of fluid is present in the pia arachnoid, a diagnosis of edema of the brain is open to question and can be made only on the assumption that the brain has been previously in a more shrunken condition.

9. We see no reason to believe that transudation can be a causative factor in the production of cerebral edema.

10. Cases of swollen or edematous brains with dry pias are decidedly uncommon at autopsy and the diagnosis of cerebral edema should be made only when actual increase in the volume of the brain matter can be proved.

I wish to thank Dr. Charles Norris for the opportunity to carry out these investigations and for his extended cooperation and criticism. I also wish to thank Drs. A. M. Pappenheimer and Cyrus W. Field of the laboratory staff for assistance and criticisms; Dr. Ernest Sachs for a critical review and Mr. Albert L. Stillman for an exposition of those principles of mechanics and physies that are involved in this paper.

128 Lexington Avenue. 